\title{
Stefnumiðaðir stjórnarhættir: Dæmi frá Orkuveitu Reykjavíkur
}

\author{
Runólfur Smári Steinpórsson, Guðrún Erla Jónsdóttir og Bjarni \\ Snæbjörn Jónsson ${ }^{1}$
}

\begin{abstract}
Ágrip
Pessi grein er á sviði stjórnarhátta og fjallar um rannsókn á eigendastefnu og stefnumiðuðum stjórnarháttum hjá Orkuveitu Reykjavíkur (OR). OR er sameignarfyrirtæki í eigu priggja sveitarfélaga. Staða og próun OR er áhugaverð vegna lagabreytinga sem knúðu á um að raforkuframleiðsla og -sala skyldi sett í sérstakt fyrirtæki og vera aðskilin frá veiturekstri OR. Í ársbyrjun 2014 var OR skipt upp í samstæðu sem samanstendur af móðurfélagi og premur dótturfélögum. Við pau tímamót var sameignarsamningur OR endurnýjaður ásamt eigendastefnu, og stjórnarhættir fyrirtækisins endurskoðaðir. Í rannsókninni er fjallað um innra samhengi milli sameignarsamnings OR, eigendastefnu og heildarstefnu fyrirtækisins og rýnt í hvernig unnið er að framkvæmd eigendastefnunnar í samstæðunni. Helstu niðurstöður eru pær að með sérstöku verklagi við rýni, mótun og eftirfylgni er stuðlað að pví að stjórn samstæðunnar hafi nauðsynlega yfirsýn til að sinna stefnutengdu hlutverki sínu í pví flókna stjórnskipulagi sem varð til við uppskiptingu fyrirtækisins. Einnig kemur fram að sérstakar aðstæður OR eftir hrunið höfðu áhrif á próun skipulags og stjórnarhátta.
\end{abstract}

\begin{abstract}
This article is about strategic corporate governance based on a case study of Reykjavik Energy (OR). OR is a partnership owned by three municipalities. Due to legislative changes requiring electricity production and sales to be operated in a separate company from its distribution, OR was reorganised in 2014 to a parent company and three subsidiaries. At that time OR's partnership agreement was renewed as well as the ownership strategy and the governance procedures were revised to reflect the new structure. A close look is taken at the processes and practices of strategy and governance that have been developed within OR to ensure that all business units operate in accordance with the ownership strategy. The main findings reveal the practices that enable the board of directors of OR to have the necessary oversight to fulfill its obligations after the reorganization of the company. The study also reveals that the specific conditions after the collapse of the financial system in Iceland in 2008 had an impact on the development of corporate governance within OR.
\end{abstract}

1 Dr. Runólfur Smári Steinpórsson er prófessor við Viðskiptafræðideild Háskóla Íslands. Netfang: rsmari@ hi.is. Guðrún Erla Jónsdóttir er stefnustjóri hjá Orkuveitu Reykjavíkur og doktorsnemi við Háskólann í Reykjavík. Netfang: gudrunerla@or.is. Dr. Bjarni Snæbjörn Jónsson er stjórnunarráðgjafi hjá Decide Act. Netfang: bsj@decideact.net.

This work is licensed under a Creative Commons Attribution 4.0 License.

DOI: https://doi.org/10.24122/tve.a.2018.15.2.2 
JEL flokkun: G34; M1; L1; L2; L3

Lykilorð: Stjórnarhættir fyrirtækja; hlutverk stjórna; eigendastefna; heildarstefna.

Keywords: Corporate governance; role of boards; ownership strategy; corporate strategy.

\section{Strategic corporate governance: the case of Reykjavík Energy}

\section{Inngangur}

Stjórnarhættir fyrirtækja (e. corporate governance) fjalla um pað hvernig fyrirtæki og stofnanir hafa umboð, fá leiðsögn, búa við aðhald og tryggja sér auðlindir með ábyrgum hætti í samfélaginu (Bonn og Pettigrew, 2009; Thomsen, 2008). Sem fyrirbæri og hugtak hafa stjórnarhættir færst sífellt ofar á sjóndeildarhring fræðimanna á síðustu árum (Filatotchev og Boyd, 2009; Gabrielsson og Huse, 2004; McNulty, Zattoni og Douglas, 2013). Fyrirbærið hefur líka fengið aukna athygli í kjölfar alpjóðlegu fjármálakrísunnar 2007-2009 (Ahrens, Filatotchev og Thomsen, 2011; Kirkpatrick, 2009; Strouhal, Bonaci og Mustata, 2012).

Góðir stjórnarhættir hafa fengið meira vægi á Íslandi á undanförnum árum. Dæmi um pað er að fyrirtæki sækjast eftir útnefningu sem fyrirmyndarfyrirtæki í stjórnarháttum (Rannsóknarmiðstöð um stjórnarhætti, 2018) og pað má líka benda á hremmingar íslensks efnahagslífs í kjölfar hruns fjármálakerfisins sem skýringu (Skýrsla rannsóknarnefndar Alpingis, 2010). Umfjöllun um góða stjórnarhætti má einnig rekja til útgáfu fyrstu leiðbeininga um góða stjórnarhætti (Viðskiptaráð Íslands, Kauphöll Íslands og Samtök Atvinnulífsins, 2004) en varð svo meira í brennidepli eftir hrunið árið 2008 (Lilja Rún Ágústsdóttir, 2010). Í kjölfar hrunsins fékk eigendastefna fyrirtækja og stofnana meira vægi og íslensk stjórnvöld settu pá fyrst fram eigendastefnu fyrir félög í eigu ríkisins árið 2009 (Fjármála- og efnahagsráðuneytið, 2017). Hvað stjórnarhætti fyrirtækis eins og Orkuveitu Reykjavíkur varðar pá hafði hrunið veruleg áhrif á skilninginn á pví hvað felst í stjórnarháttum og á stöðu fyrirtækisins (Margrét Pétursdóttir, Ása Ólafsdóttir, Ómar H. Kristmundsson og Gestur Páll Reynisson, 2012).

Prátt fyrir vaxandi umfjöllun um góða stjórnarhætti vekur athygli að lítið er um heimildir, bæði hér á landi og víðar, um tilurð og mótun eigendastefnu og hvernig stjórnir rækja skyldur sínar við framkvæmd stefnu eigenda pannig að markmiðum peirra verði náð. Pekking á eigendastefnu er pví takmörkuð, par með talið hvernig hún er yfirfærð til stjórnar og hvernig stjórn mótar síðan stjórnarhætti fyrirtækisins til að tryggja pað að umboðskeðjan sé skýr og samræmi sé milli aðgerða stjórnenda og vilja eigenda. Tilgangurinn með pessari grein er að koma með innlegg sem tekur til fræðilegrar umræðu um stjórnarhætti, sérstaklega stefnumiðaða stjórnarhætti, og er umfjöllun um niðurstöður rannsóknar á pví hvernig Orkuveita Reykjavíkur hefur unnið með eigendastefnu og beitt ákveðnu verklagi við rýni, mótun og eftirfylgni stefnu par sem verkefni stjórnenda og stjórnar eru í samspili.

Petta innlegg er viðbót við fyrirliggjandi pekkingu á stjórnarháttum á Íslandi. Til marks um pá pekkingu má nefna umfjöllun um hlutverk stjórna og starfshætti í smáum og millistórum fyrirtækjum (Eypór Ívar Jónsson, 2005, 2007, 2008, 2013) og um áhrif lagasetningar á hlutfalli milli karla og kvenna í stjórnun fyrirtækja (Auður Arna Arnardóttir og Pröstur Olaf Sigurjónsson, 2017; Guðbjörg Linda Rafnsdóttir, Porgerður Einarsdóttir og Jón Snorri Snorrason, 2014). Einnig hefur verið fjallað um áhrif hrunsins á stjórnarhætti (Pröstur Olaf Sigurjónsson, 2010) og á pætti stjórnarháttum sem geta átt pátt í að endurheimta traust á fyrirtækjum og stofnunum (Auður Arna Arnardóttir og Pröstur Olaf Sigurjónsson, 2018). Einnig má nefna meistararitgerðir um stjórnarhætti á Íslandi, sbr. ritgerð um stjórnir hlutafélaga, starfshætti og ábyrgð (Erna Sigurðardóttir, 2003) og ritgerð um stjórnarhætti fyrirtækja frá íslensku sjónarhorni, par sem rýnt var í ársreikninga fyrirtækja og viðtöl við stjórnarmenn voru tekin (Lilja Rún Ágústsdóttir, 2010). Fjöldi hagnýtra greina hefur líka 
birst um efnið í vikuritinu Vísbendingu og á vefsíðum rannsóknarsetra um stjórnarhætti við íslenska háskóla. Ofangreind samantekt gefur innsýn í pau verk sem eru fyrirliggjandi á íslensku en segja má að brýn pörf sé á frekari rannsóknum, ekki síst par sem opinber fyrirtæki eru til skoðunar.

Áherslan í pessari grein er á stefnutengt hlutverk stjórna, ekki síst í tengslum við ferli stefnumiðaðs starfs. Eitt meginhlutverk stjórna fyrirtækja er að hafa forystu um mótun stefnu og að fylgjast með framvindu markmiða og viðmiða til lengri og skemmri tíma. Prátt fyrir mikilvægi pessa hlutverks (Hendry og Kiel, 2004) er hlutur stjórna í framkvæmd stefnu lítt rannsakaður (Bonn og Pettigrew, 2009; Brauer og Schmidt, 2007). Stjórnir fyrirtækja bera mikla ábyrgð og pær sinna fjölpættum verkefnum (Solomon og Solomon, 2004). Stjórnir gegna mikilvægu eftirlitshlutverki en jafnframt er peim ætlað að veita forystu, ekki síst pegar kemur að stefnutengdu hlutverki peirra (Cardale, 2014; Pugliese, Bezemer, Zattoni, Huse, Van den Bosch og Volberda, 2009; Smerdon, 2007).

Markmiðið með pessari grein er að skila framlagi til pekkingar á pví hvernig stefnumiðaðir stjórnarhættir og sérstaklega eigendastefna gerir stjórnum fyrirtækja og stofnana kleift að rækja skyldur sínar við pað að fylgja eftir vilja og markmiðum eigenda. Greinin byggir á raundæmisrannsókn innan Orkuveitu Reykjavíkur (OR) og skoðað er með hvaða hætti stjórn samstæðu OR og eftir atvikum stjórnir dótturfélaga OR stuðla að framkvæmd eigendastefnu innan hennar og fylgja eftir heildarstefnu samstæðunnar. Markmið rannsóknarinnar er að fjalla um pá reynslu sem hefur fengist af pví starfi, draga lærdóm og nýta í fræðilega og hagnýta umfjöllun um hlutverk stjórna í framkvæmd stefnu.

Rannsóknarspurningin er:

\section{Hvernig má vinna að framkvæmd formlegrar eigendastefnu og stuðla að stefnumiðuðum stjórnarháttum?}

Til að svara rannsóknarspurningunni er skoðað hvernig stjórn OR og lykilaðilar samstæðunnar útfæra hlutverk sitt varðandi pað að framfylgja eigendastefnu, sinna stefnumótun og starfa í takti við samræmda stjórnarhætti. OR er opinbert fyrirtæki og sinnir sérleyfisskyldri starfsemi sem er með beinum hætti á ábyrgð sveitarfélaga auk samkeppnisstarfsemi. Vegna kröfu í raforkulögum, par sem kveðið er á um aðskilnað raforkudreifingar annars vegar og framleiðslu og sölu á raforku hins vegar, var starfsemi OR skipt upp árið 2014 og stofnuð sjálfstæð dótturfélög. Uppskiptingin fól í sér mikla áskorun fyrir fyrirtækið varðandi skipulag, stefnumiðað starf og stjórnarhætti. Rannsóknin á stjórnarháttum OR byggir á pví að draga megi áhugaverðan lærdóm af reynslu félagsins.

Í upphafi greinarinnar er farið yfir stjórnarhætti, stefnu og stefnumiðaða stjórnarhætti. Pá er gerð grein fyrir aðferðum og framkvæmd rannsóknarinnar á stjórnarháttum OR og niðurstöðum lýst. Pví næst er fjallað um hvernig stefnumiðuðum stjórnarháttum er hagað innan samstæðu OR og í lokin er lærdómurinn dreginn saman og tillögur að frekari rannsóknum settar fram.

\section{Hlutverk stjórna og stjórnarhættir}

Hlutverk stjórna er margpætt (Solomon og Solomon, 2004). Stjórnum ber að fara með yfirstjórn fyrirtækja og hafa eftirlit með starfsemi peirra og samkvæmt lögum bera pær endanlega ábyrgð á starfseminni. Ábyrgð stjórna er umfangsmikil og felst í pví að fara með málefni fyrirtækisins milli hluthafafunda, koma að mótun stefnu ásamt pví að hafa eftirlit með pví að stefna fyrirtækis, skipulag og rekstur sé í réttu og góðu horfi (Thomsen, 2008).

Eins og greint var frá í inngangi er pessi grein afmörkuð við pað hlutverk stjórnarhátta og verkefni stjórna fyrirtækja sem snúa að vinnu og ábyrgð peirra á atriðum sem tengjast stefnu fyrirtækja, ekki síst heildarstefnu. Stjórnarhættir fjalla, eins og umfjöllun í inngangi ber með sér, um yfirráð, samspil við umhverfið og ábyrgð á skipulegri framvindu í 
starfsemi fyrirtækja og stofnana. Umfjöllun um fyrirbærið hefur verið mikil og vaxandi á síðustu árum en staða pekkingar á pví er óviðunandi (Ahrens o.fl., 2011), m.a. vegna pess hversu viðfangsefnin eru flókin, breytur margar og mikil vandkvæði við mælingar. Hugtakið stefnumiðaðir stjórnarhættir hefur verið að ryðja sér til rúms einkum í ljósi vaxandi áherslu á ábyrgð stjórna við mótun og eftirfylgni stefnu.

Hér er fjallað nánar um stjórnarhætti almennt og í framhaldi er varpað ljósi á pá pætti sem hér eru skilgreindir sem stefnumiðaðir stjórnarhættir, en par er átt við pað afmarkaða hlutverk stjórna sem snýr að virkri pátttöku í stefnumiðaðri stjórnun peirra fyrirtækja og stofnana sem viðkomandi stjórn ber ábyrgð á.

\subsection{Stjórnarhættir fyrirtækja}

Stjórnarhættir taka mið af lögum og reglum á hverjum stað. Skipulagið (e. corporate governance system) er mismunandi eftir svæðum í heiminum og fer eftir aðstæðum, hefðum og venjum í viðkomandi landi (Filatotchev og Boyd, 2009; Thomsen, 2008). Fyrirliggjandi eru margar skilgreiningar á hugtakinu (Hodges o.fl., 1996; L'Huillier, 2014; Pirson og Turnbull, 2015; Turnbull, 1997).

Stjórnarhættir ná utan um pá skipan mála sem fylgir eftir réttindum og ábyrgð peirra aðila sem hafa hagsmuna að gæta í viðkomandi skipulagsheild (Aoki, 2001; Filatotchev og Boyd, 2009). Umfjöllun um stjórnarhætti byggir á mörgum kenningum sem falla undir mismunandi sjónarhorn (L'Huillier, 2014). Nálgun að stjórnarháttum getur pví verið frá pví að vera pröng og frekar lokuð nálgun að samspili fyrirtækis og eigenda pess yfir í pað að vera opin og víðtæk varðandi pað hvernig megi fylgja eftir fyrirtækjum pannig að pau séu rekin á áhrifaríkan og skilvirkan hátt (Aguilera, Filatotchev, Gospel og Jackson, 2008). Víðtæk skilgreining á hugtakinu segir stjórnarhætti vera net samskipta milli fyrirtækis og eiganda pess auk samskipta milli fyrirtækisins og hagsmunaaðila, svo sem starfsmanna, viðskiptavina, lánadrottna og fleiri (Pirson og Turnbull, 2015; Solomon og Solomon, 2004).

Hér á landi, ekki síst á hagnýtum vettvangi, hefur verið notast við pá skilgreiningu að stjórnarhættir fyrirtækja lúti að príhliða sambandi milli hluthafa, stjórnar og stjórnenda (Eypór Ívar Jónsson, 2005; Viðskiptaráð Íslands o.fl., 2009). Jafnframt hefur verið bent á að opinber fyrirtæki purfi ekki síður en einkafyrirtæki að huga að stjórnarháttum (Viðskiptaráð Íslands o.fl., 2008). Dreifing ábyrgðar og auðlinda frá hinu opinbera til fyrirtækja í peirra eigu dregur fram pörf á mörkun umboðs og valds milli aðila (Gnan, Hinna, Monteduro og Scarozza, 2011; Sjöstrand o.fl., 2016). Sjónarmið hafa verið sett fram hérlendis um að opinber fyrirtæki purfi að ganga lengra en önnur fyrirtæki til að tryggja trúverðugleika sinn (Viðskiptaráð Islands o.fl., 2008) og erlendis hefur verið kallað eftir frekari rannsóknum á fyrirtækjum sem sinna opinberri starfsemi (Calabró, Torchia og Ranalli, 2013; Farrell, 2005; Grossi og Reichard, 2008).

Margar fræðilegar kenningar eru tengdar rannsóknum og umræðu um stjórnarhætti (L'Huillier, 2014), en að mati Mallin (2004) eiga prjár peirra beinan hátt í próun stjórnarhátta. Par má fyrst nefna kenninguna um veitingu umboðs og um umboðsvanda (e. agency theory) sem felur í sér að markmið og sjónarmið eiganda og stjórnenda geta stangast á (Fama og Jensen, 1983; Jensen og Meckling, 1976), svo kenninguna um viðskiptakostnað (e. transaction cost theory) sem gengur út á að lágmarka kostnað (Coase, 1937; Willamsson, 1975) og í priðja lagi kenninguna um hagsmunaaðila (e. stakeholder theory) sem skoðar hagsmuni peirra aðila sem beint og óbeint koma að rekstri fyrirtækis (Freeman, 1994). Til viðbótar pessum premur er mikilvægt að nefna tvær kenningar. Önnur, um aðgengi að auðlindum (e. resource dependency theory), bendir meðal annars á virkari pátttöku stjórnarmanna í að tryggja aðgang fyrirtækja að mikilvægum auðlindum fyrir próun fyrirtækja (Pfeffer og Salancik, 1978). Hin dregur fram pjónustuhlutverk stjórnarmanna (e. stewardship theory), en par er pví lýst hvernig stjórnarmenn vinna að hagsmunum fyrirtækisins út frá markmiðum umbjóðenda sinna (Davis, Schoorman og Donaldsson, 1997).

Filatotchev og Boyd (2009) benda á að kenningin um umboðsvanda hafi verið fyrir- 
ferðarmikil en sjónarhornið er pröngt. Af sams konar tilefni hafa Calabró o.fl. (2013) bent á mikilvægi pess að styðjast við fleiri fræðileg sjónarhorn. Margir fleiri pættir en skilgreining umboðs, eftirlit og umboðsvandi skipta máli, ekki síst atriði sem varða pjónustuhlutverk stjórnarmanna og mikilvægi peirra pegar kemur að pví að tryggja árangur fyrirtækja og stofnana í stöðu par sem auðlindir geta verið takmarkaðar (Johnson, Scholes, og Whittington, 2008).

Í yfirliti yfir rannsóknir á sviði stjórnarhátta röðuðu Daily, Dalton og Cannella (2003) pessu stefnutengda viðfangsefni meðal peirra mest lofandi til frekari rannsókna auk pess sem kallað hefur verð sérstaklega eftir rannsóknum sem leggja áherslu á hlutverk stjórna í stefnumótun (Pugliese o.fl., 2009; Pye og Pettigrew, 2005; Schmidt og Brauer, 2006;). Niðurstaða Pugliese o.fl. (2009) er að ekki séu fram komin fullnægjandi svör við pví með hvaða hætti framlag stjórna til stefnumótunar gæti best verið sem best og pví sé petta rannsóknarefni ennpá bæði viðeigandi og krefjandi. Pugliese o.fl. (2009) hvetja ennfremur fræðimenn til að kafa dýpra í hið „,svarta box“ (e. black box), sem rannsóknir á sviði stjórna eru, til að hægt sé að próa betri skilning á viðfangsefninu. Að mati peirra byggja flestar rannsóknir á sviði hlutverks stjórna á pví að horft er utan frá og inn og pess vegna er talað um stjórnir sem hið „,svarta box“ sem erfitt að fá aðgengi að til að öðlast dýpri skilning á pví starfi sem stjórn innir af hendi (Pugliese o.fl., 2009).

\subsection{Stefnumiðaðir stjórnarhættir}

Stefna er nátengd próun og breytingum (Johnson o.fl., 2008) en hún er um leið sameiginleg leiðarlýsing allra peirra sem samkvæmt henni starfa (Andrews, 1987) og pannig grundvöllur pess að dreifa ábyrgð og forræði (Chandler, 1962). Hún er oft fólgin í athöfnum sem fyrirtæki fyrirhugar og framkvæmir til að bregðast við breytingum, jafnvel til að kalla pær fram á árangursríkan hátt (Ansoff, 1965). Umhverfi fyrirtækja tekur stöðugum breytingum og eins og Porter (1996) nefnir purfa fyrirtæki að vera sveigjanleg svo pau séu fljót að bregðast við peim og mögulegri samkeppni. Stefna tengir líka fyrirtæki og starfsfólk pess við tilgang sem endurspeglar parfir fyrirtækis og einstakra eininga pess (Drucker, 1974). Stefna getur pjónað margs konar tilgangi og verið hvoru tveggja stuðningur og samræmingarafl við daglegar ákvarðanir (Grant, 2010). Stefna getur líka verið yfirlýsing um áherslur og virkað pannig sem upplýsingagjöf og sem grundvöllur hvatningar (Grant, 2010).

Mintzberg, Ahlstrand og Lampel (1998) segja, og byggja par meðal annars á Chaffee (1985), að til séu mismunandi nálganir að hugtakinu stefnu. Fyrirtæki hafi til að mynda heildarstefnu (e. corporate strategy) sem svarar spurningunni um pað í hvaða starfsemi fyrirtækið ætti að vera og viðskiptastefnu (e. business strategy) sem svarar pví hvernig ætlunin er að keppa í tiltekinni starfsemi (Johnson o.fl., 2008). Til viðbótar við heildarstefnu, sem tekur til heildarumfangs skipulagsheildarinnar, og viðskiptastefnu, sem snýst um pað hvernig viðskiptaeiningar, sem eru hluti af skipulagsheildinni, ætla að keppa hver á sínum markaði, er rekstrarstefna (e. operating strategy) sem hefur prengsta umfangið (Johnson o.fl., 2008). Rekstrarstefna snýr að pví hvernig samsettir pættir skipulagsheildarinnar skila árangri til bæði heildar- og viðskiptastefnu hvað varðar auðlindir, fólk og ferla (Johnson o.fl., 2008).

Atriðin sem tengjast stefnu falla undir pað sem skilgreina má sem stefnumiðaða stjórnun fyrirtækja. Stefnumiðuð stjórnun nær yfir allt samhengi stefnu; mótun stefnu, framsetningu stefnu, innleiðingu og eftirfylgni með framvindu stefnu (Ingi Rúnar Eðvarðsson, Runólfur Smári Steinpórsson og Helgi Gestsson, 2011; Runólfur Smári Steinpórsson, 2003a, 2003b). Pegar kemur að framkvæmd stefnu er mikilvægt að huga vel að skipulagi fyrirtækja (Runólfur Smári Steinpórsson, Anna Marín Pórarinsdóttir og Einar Svansson, 2018).

Eitt helsta hlutverk stjórna snýr að stefnumótun og árangri fyrirtækisins sem á í hlut (Brauer og Schmidt, 2007; Goold og Campbell, 1990; Rindova, 1999; Zahra, 1990). Prátt 
fyrir samhljóm um stefnutengt hlutverk stjórna er deilt um pað hvers eðlis aðkoma stjórna skuli helst vera (Helmer, 1996) og óljóst er með hvaða hætti stjórnir geta eða ættu að uppfylla petta hlutverk (Brauer og Schmidt, 2007; Hendry og Kiel, 2004; Stiles, 2001), enda er skortur á rannsóknum og sértækri pekkingu á viðfangsefninu (Hendry og Kiel, 2004). Stefnutengt hlutverk stjórna, sérstaklega hlutur stjórnar í framkvæmd stefnu, hefur ekki verið rannsakaður til hlítar (Brauer og Schmidt, 2007; Daily o.fl., 2003; Fiegener, 2005; Hendry og Kiel, 2004).

Hér að framan hefur verið fjallað um stjórnarhætti fyrirtækja og gerð grein fyrir helstu fræðilegu sjónarhornum og skilgreiningum á fyrirbærinu. Pó ekki sé til nein ein alpjóðlega viðurkennd skilgreining á stjórnarháttum ber skilgreiningum saman um mikilvægi og ábyrgð stjórna í stjórnarháttum fyrirtækja. Ábyrgð stjórna er mikil og ekki síst með tilliti til hlutverks peirra er tengist stefnumiðaðri stjórnun, p.m.t. við mótun stefnu, framsetningu stefnu, stefnumarkandi markmiðssetningu, áætlanagerð, innleiðingu og eftirfylgni með stefnu.

Pessi áhersla á stefnutengda pætti er í pessari grein dregin saman í eitt hugtak: stefnumiðaða stjórnarhætti. Með stefnumiðuðum stjórnarháttum er átt við pað vinnulag og pau verkfæri sem stjórn beitir til að sinna stefnutengdu hlutverki sínu. Рað liggur fyrir að mikilvægt verkefni stjórna fyrirtækja er að pær leggi sitt af mörkum til stefnu fyrirtækja (Brauer og Schmidt, 2007; Goold og Campell, 1990; Rindova, 1999; Zahra, 1990) en um pað með hvaða hætti stjórnir ættu að uppfylla pessa ábyrgð er minna vitað og pví pörf á frekari rannsóknum á pessu sviði (Hendry og Kiel, 2004). Segja má að hugtakið stefnumiðaðir stjórnarhættir falli vel að ákalli fræðanna um mikilvægi pess að skoða nánar stefnutengt hlutverk stjórna (Daily o.fl., 2003; Pugliese o.fl., 2009; Pye og Pettigrew, 2005; Schmidt og Brauer, 2006).

Til að varpa frekara ljósi pað sem fellur undir og tengist stefnumiðuðum stjórnarháttum er vísað til umfjöllunar og ábendinga Bonn og Pettigrew (2009) um lykilhlutverk stjórna fyrirtækja og stofnana. Par segir að pátttaka í stefnumiðaðri ákvarðanatöku sé eitt af premur meginverkefnum stjórna (Bonn og Pettigrew, 2009). Nálgun stjórna að hinu stefnutengda hlutverki getur verið frá pví að vera óvirk yfir í pað að vera virk (Demb og Neubauer, 1992). Stjórnir sem eru virkar í hinu stefnutengda hlutverki sinna pví með ráðgefandi hætti (Johnson, Daily og Ellstrand, 1996) og par hafa óháðir stjórnarmenn tækifæri til að opna augu stjórnarmanna og stjórnenda fyrir nýjum möguleikum (Judge og Zeithaml, 1992). Bonn og Pettigrew (2009) benda einnig á rannsóknir sem sýna að stjórnarmenn hafi jafnan með höndum pað verkefni að taka ákvarðanir sem hafi stefnumarkandi pýðingu. Í mörgum tilvikum hafi stjórnarmenn einnig mótandi áhrif á pær stefnumarkandi ákvarðanir sem teknar eru, en miklu sjaldnar sé um pað аð ræða að stjórnir sinni stefnutengdu hlutverki sínu með pví að hafa mótandi áhrif á aðstæður, inntak og pað atferli sem væri einkennandi fyrir hið stefnumiðaða starf í fyrirtækinu (McNulty og Pettigrew, 1999).

Prátt fyrir tvöföldun birtra greina um stjórnarhætti á árunum 2004-2011 (Ahrens o.fl., 2011) er ekki að finna að hið stefnutengda hlutverk stjórna hafi verið rannsakað til hlítar og allra síst páttur stjórna í innleiðingu eða framkvæmd stefnu (Bonn og Pettigrew, 2009; Brauer og Schmidt, 2007; Fiegener, 2005; Hendry og Kiel, 2004; Pugliese o.fl., 2009; Runólfur Smári Steinpórsson, 2017). Markmið pessarar tilviksrannsóknar er pví að eiga pátt í að bæta úr og skoða dæmi um stefnutengda stjórnarhætti í tilteknu fyrirtæki til að auka lærdóm og skilning á stefnumiðuðum stjórnarháttum.

Eins og fram kom í inngangi greinarinnar er markmiðið að rýna í stefnumiðaða stjórnarhætti í tengslum við innleiðingu eigendastefnu og lýsa raundæmi sem sýnir hvernig stjórn fyrirtækisins leitast við að uppfylla stefnutengt hlutverk sitt. Næsti kafli fjallar nánar um pá rannsóknaraðferð sem notast var við til að ná fram pessu markmiði. 


\section{Rannsóknaraðferð}

Til að rifja upp pá snýst rannsóknarspurning greinarinnar, sem kynnt var í inngangi, um pað hvernig megi hrinda í framkvæmd formlegri eigendastefnu og stuðla að stefnumiðuðum stjórnarháttum. Til að svara pessari spurningu var gerð raundæmisrannsókn á pví hvernig hlutverk stjórnar OR hefur verið útfært varðandi stefnumótun og samræmda stjórnarhætti. Hér á eftir er gerð grein fyrir vali á rannsóknarnálgun og aðferðum auk pess sem gerð er grein fyrir pví hvernig staðið var að framkvæmd rannsóknarinnar og úrvinnslu gagna. Að lokum er komið inn á stöðu höfunda gagnvart rannsóknarefninu.

\subsection{Aðferðarfræði og val á rannsóknaraðferð}

Par sem ekki hafa verið framkvæmdar margar raundæmisrannsóknir (e. case study research) á stjórnarháttum hér á landi, sbr. umfjöllun í inngangi, er við hæfi að gerðar séu könnunarathuganir sem byggja á einu eða fleiri raundæmum (e. explorative case study), par sem áherslan er á að leita skilnings á viðfangsefninu (Yin, 2009). Pessi rannsóknaraðferð kallast á við eigindlega rannsóknarhefð við gagnaöflun, en í raundæmisrannsóknum er stuðst við margs konar gögn, bæði frumgögn og fyrirliggjandi gögn (Eisenhardt, 1989; Yin, 2009). Rannsóknaraðferðir sem byggja á eigindlegri rannsóknarhefð eru jafnan túlkandi og byggja á kenningum um að veruleikinn sé félagslega skapaður. Slík nálgun á viðfangsefni styðst enn fremur við aðleiðslu sem felur í sér að kenningar og tilgátur byggja á gögnunum sjálfum en eru ekki settar fram í upphafi rannsóknar (Eisenhardt og Graebner, 2007; Taylor og Bogdan, 1998).

Rannsóknin á stefnumiðuðum stjórnarháttum í Orkuveitu Reykjavíkur er pví skilgreind sem raundæmisrannsókn af könnunartoga (e. explorative case study). Samkvæmt Yin (2009) má skipta raundæmisrannsóknum í fjóra meginflokka; Eitt raundæmi skoðað heildrænt; Raundæmi skoðað sem tekur til fleiri en einnar skipulagseiningar; Mörg raundæmi skoðuð heildrænt; Mörg raundæmi skoðuð sem taka til fleiri en einnar skipulagseiningar.

Sú rannsókn sem hér er greint frá byggist á einu raundæmi innan OR sem skoðað er heildrænt. Markmiðið var að draga fram og lýsa með hvaða hætti leitast er við að uppfylla stefnutengt hlutverk stjórnar. •að var ekki tilgangur rannsóknarinnar að leggja mat á kosti eða galla pess fyrirkomulags sem lýst er. Í framhaldi af úttekt á OR var bent á mikilvægi pess að próa skipulag og ferla til að styðja við ákvarðanatöku stjórnar og er markmið pessarar rannsóknar að varpa ljósi á pað ferli sem viðhaft er hjá OR. Í pessari raundæmisrannsókn hefur verið unnið með fyrirliggjandi skrifleg gögn og viðtalsgögn auk athugana sem gerðar voru með beinni pátttöku á vettvangi (sjá yfirlit í viðauka). Nú verður vikið nánar að öflun og úrvinnslu gagna.

\section{2 Öflun og úrvinnsla gagna}

Í raundæmisrannsóknum er tækifæri til að nýta fjölbreytt gögn. Helstu uppsprettur gagna eru fyrirliggjandi skrifleg gögn (e. documents), skjalageymslugögn (e. archival records), viðtöl, beinar athuganir, pátttökuathuganir og ápreifanlegir hlutir (e. physical artifacts) (Yin, 2009). Раð er mikilvægt að byggja rannsókn upp á góðum skipulögðum gagnagrunni, gæta samhengis og hafa góða yfirsýn yfir gögnin og hvernig best er að vinna úr peim (Yin, 2009).

Pó svo að meiri áhersla sé lögð á réttmæti í eigindlegum rannsóknum, pað er að rannsóknin meti pað sem til er ætlast, pá er einnig lögð áhersla á áreiðanleika (Taylor og Bogdan, 1998). Рað er á ábyrgð pess sem framkvæmir rannsóknina að notast við nákvæm, skipulögð og öguð vinnubrögð og mikilvægt að gerð sé grein fyrir pví hvernig gagna var aflað og hvernig úrvinnsla fór fram (Yin, 2009).

Gagnaöflun fór fram hjá Orkuveitu Reykjavíkur (OR) frá nóvember 2016 til júní 2017. Skoðuð voru fyrirliggjandi gögn og kynningar um vinnuferli við rýni stefnu, markmiða 
og mælikvarða í samstæðu OR. Pá voru skoðuð gögn um vinnuferli við innleiðingu stefnu auk pess sem skoðuð voru rekstrarhandbókarskjöl sem geyma upplýsingar um skipulag samstæðunnar, sameignarsamning, eigendastefnu, lykilstefnur, markmið og mælikvarða. Pá var skoðað útgefið efni um framfylgd eigendastefnu OR sem birt er árlega á vef fyrirtækisins. Við úrvinnslu voru upplýsingar skráðar niður á skipulegan hátt og peim haldið til haga í par til gerðum möppum í skjalavistunarkerfi. Bein athugun var einnig gerð á pví hvernig pví verklagi, sem aflað var gagna um, var hrint í framkvæmd á stjórnarfundum OR. Skráðar voru niður upplýsingar úr beinum athugunum og pær vistaðar. Til pess að fá frekari upplýsingar um próun stjórnarhátta hjá OR voru tekin hálfstöðluð viðtöl við prjá stjórnendur samstæðunnar. Með hliðsjón af rekjanleika til einstaklinga er ekki unnt að greina frá stöðu peirra innan samstæðunnar. Hinn hálfstaðlaði viðtalsrammi var sá sami fyrir alla stjórnendurna og sami einstaklingur tók öll viðtölin. Viðtölin voru greind og kóðuð, og niðurstöður vistaðar. Raundæmið um „Stefnu og stjórnarhætti OR“ (sjá kafla 4) var í kjölfarið skrifað út frá gögnum sem safnað hafði verið og hliðsjón af peim viðtölum sem voru tekin. Pví næst var fjórði stjórnandinn beðinn um að lesa yfir niðurstöðurnar um stefnu og stjórnarhætti OR og í óstöðluðu og opnu viðtali, sem sami rannsakandi tók, var hann beðinn um að gefa álit sitt á réttmæti lýsingarinnar og ábendingar voru skráðar jafnóðum. Öll viðtölin voru tekin hjá OR. Markmiðið var að fá aukinn skilning á peim gögnum sem aflað var um eigendastefnu og verklag sem viðhaft er við innleiðingu og framkvæmd stefnunnar.

\subsection{Staða höfunda og áskoranir við rannsóknina}

Raundæmisrannsóknir eru vandmeðfarnar og hafa verið gagnrýndar meðal annars fyrir pað að svigrúm myndist fyrir hlutdrægni par sem rannsakandi hafi mikið frjálsræði um gögn og niðurstöður (Yin, 2009). Eðli málsins samkvæmt hefur raundæmisrannsókn, sem byggir á einu eða fáum dæmum, ekki alhæfingargildi í peirri merkingu að niðurstöður megi yfirfæra á öll önnur fyrirtæki. Slík rannsókn getur hins vegar haft pann ávinning í för með sér að niðurstöður megi nýta sem framlag til pekkingar af fræðilegum toga (e. analytical generalization; Yin, 2009) og pær geta haft hagnýtt gildi fyrir fyrirtæki og stjórnendur (Taylor og Bogdan, 1998). Forsenda fyrir pví að lesendur njóti slíks ávinnings er að rannsóknin sem um ræðir sé vel úr garði gerð og liður í pví er m.a. að fyrirtækið sem byggt er á staðfesti að gögn og upplýsingar séu réttar. Trúverðugleikinn er jafnframt meiri ef engin leynd er yfir pví um hvaða fyrirtæki er að ræða.

Eins og fram hefur komið er gerð rannsókn á stefnumiðuðum stjórnarháttum í einu tilteknu dæmi, p.e. samstæðu Orkuveitu Reykjavíkur. Rannsóknin er birt með fullri heimild frá Orkuveitu Reykjavíkur og kaflinn um niðurstöður rannsóknarinnar var borinn undir forsvarsmenn fyrirtækisins til að sannreyna að rétt væri frá sagt. Рað er einnig mikilvægt að gera grein fyrir stöðu höfunda gagnvart viðfangsefninu. Höfundar eru prír. Tveir höfundanna hafa verið í fleiri en einu hlutverki í tengslum við rannsóknina. Pað er sem rannsakandi og stefnustjóri fyrirtækisins sem rannsakað er og sem rannsakandi og ráðgjafi fyrirtækisins.

Höfundar hafa verið vakandi fyrir mögulegum hagsmunaárekstrum og lagt sig fram um að láta ekki ólík hlutverk hafa nein óeðlileg áhrif á umfjöllun um niðurstöður rannsóknarinnar, m.a. í gegnum verkaskiptingu við ritun og frágang greinarinnar.

\section{Stefna og stjórnarhættir hjá OR}

Í pessu yfirliti yfir niðurstöður rannsóknarinnar er í upphafi farið yfir bakgrunn Orkuveitu Reykjavíkur (OR) og stjórnskipulagi lýst auk pess sem fjallað er um eigendastefnu OR og ábyrgð stjórnar OR. Samkvæmt raforkulögum nr. 65/2003 var OR skylt að skipta upp starfseminni og skilja að dreifingu rafmagns frá framleiðslu og sölu raforku. Við pær breytingar varð OR að samstæðu, og pað gerði auknar kröfur til stjórnarhátta. Samhliða var OR að vinna sig út úr erfiðri stöðu sem fyrirtækið hafnaði í eftir hrunið. Pessar að- 
stæður knúðu fram ákveðnar breytingar í stjórnarháttum samstæðunnar sem kölluðu á nýja hugsun í pví hvernig stjórnin starfar, hvernig hún mótar leiðbeinandi stefnu fyrir heildina og fylgist með árangri hennar.

\subsection{Starfsemi og skipulag hjá OR}

OR er sameignarfyrirtæki í eigu priggja sveitarfélaga, Reykjavíkurborgar (93,5\%), Akranesskaupstaðar (5,5\%) og Borgarbyggðar (1\%). Í ársbyrjun 2014 var OR skipt upp í samstæðu að lagaboði (raforkulög nr. 65/2003), eins og fjallað er um hér á eftir. Sú uppskipting fól í sér mikla áskorun. Með henni voru settar sjálfstæðar stjórnir yfir nýju dótturfélögin og framkvæmdastjórar yfir hvert og eitt. Boðvald forstjóra var pví ekki lengur til staðar eftir uppskiptingu. Allt kapp var lagt á að prátt fyrir uppskiptingu myndi nýja samstæðan starfa sem ein heild í samræmi við pær áherslur sem höfðu verið mótaðar og byggðar á eigendastefnu OR (viðtal við stjórnanda hjá OR).

Um Orkuveitu Reykjavíkur (OR) gilda lög nr. 136/2013. Í lögunum kemur fram að aðgreining starfsemi OR frá starfsemi dótturfélaga skuli vera í samræmi við ákvæði laga hverju sinni og pess skuli gætt að rekstur OR og dótturfélaga skuli ekki niðurgreiddur af einkaleyfisstarfsemi eða verndaðri starfsemi (Lög um Orkuveitu Reykjavíkur nr. 136/2013). Með breytingu á raforkulögum (nr. 65/2003), sem gerð var árið 2008, voru raforkufyrirtæki skylduð til aðskilnaðar á sérleyfis- og samkeppnishluta rekstrarins frá og með 1. júlí 2009. Uppskiptingu OR var ítrekað frestað (viðtal við stjórnanda hjá OR) en kom loks til framkvæmda 1. janúar 2014. OR aðskildi pá samkeppnishluta rekstrarins frá sérleyfishlutanum, hinum hefðbundna veiturekstri. Í lögunum segir að í peim tilgangi að koma í veg fyrir niðurgreiðslu samkeppnisrekstrar sé heimilt að mæla fyrir um fjárhagslegan aðskilnað, par með talinn „,fyrirtækjaaðskilnað milli samkeppnisstarfsemi og starfsemi sem nýtur sérleyfis eða hefur sambærilega stöðu“ (Raforkulög nr. 65/2003).

Orkuveita Reykjavíkur sem móðurfélag og dótturfélögin mynda eftir uppskiptingu samstæðu. Móðurfélagið veitir dótturfélögunum Veitum, Orku náttúrunnar og Gagnaveitu Reykjavíkur stoðpjónustu og pau koma fram undir eigin merkjum, eins og sést á mynd 1.

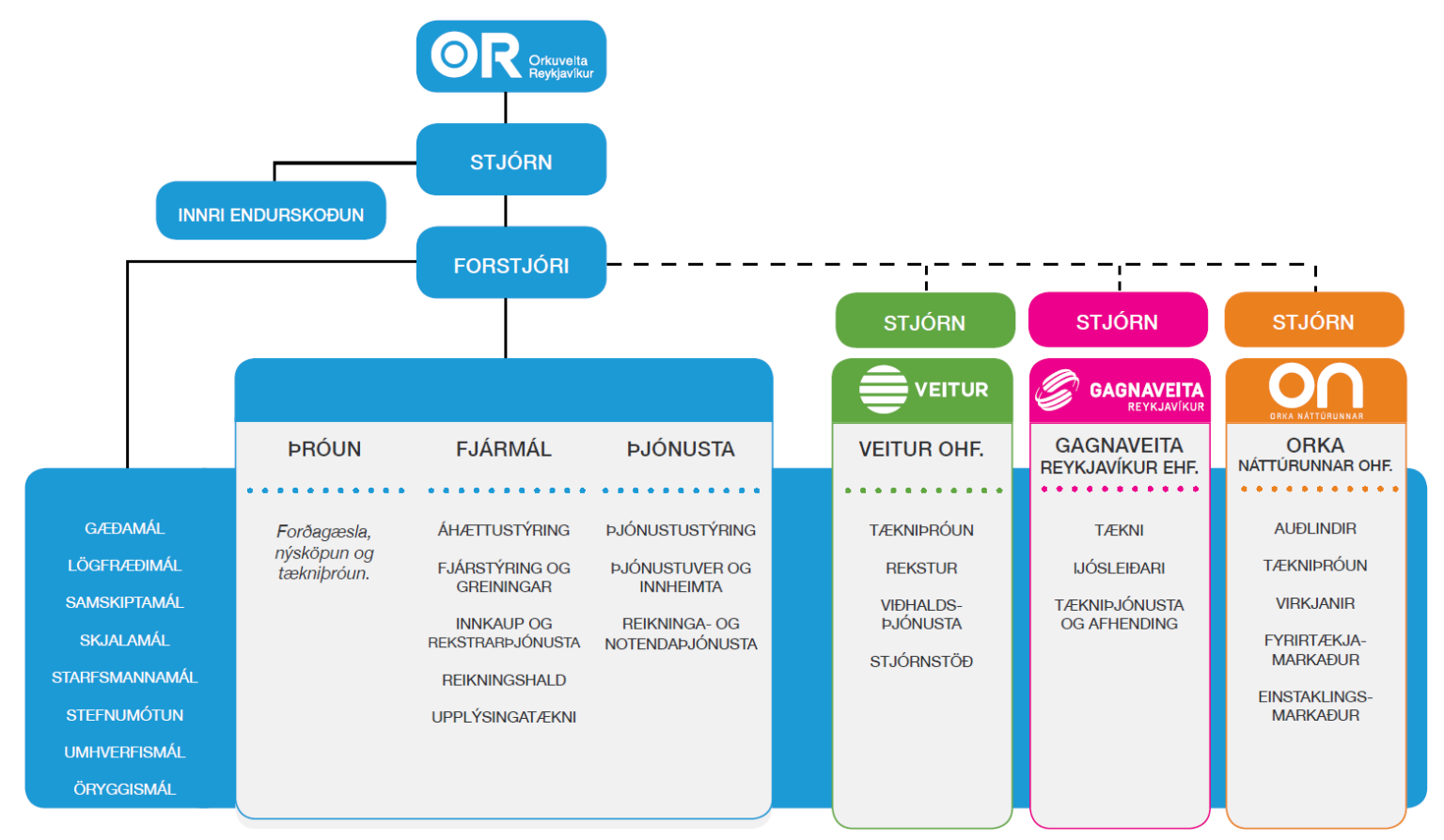

Mynd 1. Skipulag samstæðu OR

Heimild: Orkuveita Reykjavíkur, 2017. Sótt af https://www.or.is/um-or/skipulag-og-stjornendur 
Í lögum um OR, sem marka samstæðunni pann ramma sem hún starfar innan, segir að eigendur fyrirtækisins skuli gera með sér sameignarsamning (Lög um Orkuveitu Reykjavíkur nr. 136/2013). Í sameignarsamningi kemur fram að eigendur skuli marka OR og dótturfélögum pess stefnu um tilgang og markmið rekstrarins, rekstrarform, starfshætti og arðgreiðslur (Sameignarsamningur, 2014). Pessum atriðum er lýst í eigendastefnu OR sem fjallað er um næst.

\subsection{Eigendastefna og önnur stefnuskjöl OR}

Mikilvægt er að taka fram að staða OR eftir hrun íslenska fjármálakerfisins hafði áhrif á pað hvernig OR brást við í próun stjórnarhátta (viðtal við stjórnanda hjá OR; Guðrún Erla Jónsdóttir, 2018; Margrét Pétursdóttir o.fl., 2012). Í framhaldi af úttekt var unnið að pví að byggja upp stjórnendateymi og sameiginlega sýn og gildi fyrir fyrirtækið og megináherslur í starfsemi pess voru markaðar til framtíðar (viðtal við stjórnanda hjá OR; Guðrún Erla Jónsdóttir, 2018).

Verkefni við mótun eigendastefnu Orkuveitu Reykjavíkur (OR) hófst árið 2010 og var lokið 2012. Stefnumótun var unnin á premur sviðum samtímis; 1) eigendur varðandi eigendastefnu 2) stjórn varðandi heildarstefnu, stefnu málaflokka og lykilárangur 3) stjórnendur varðandi stefnur sviða og dótturfélaga. Með eigendastefnu var leitast við að skýra hlutverk og ábyrgð eigenda og tryggja pátttöku peirra í ákvörðunum um mikilvæg málefni og stefnumörkun (Eigendastefna Orkuveitu Reykjavíkur, 2014).

Eigendastefnan hafði pað аð markmiði að tryggja lýðræðislega, faglega og skilvirka stjórnun fyrirtækisins. Með skýrri stefnumörkun eigenda, vel skilgreindu hlutverki fyrirtækisins, skýru umboði handhafa eigendavalds, stjórnar OR og forstjóra, ásamt lýsingu á kröfum um stjórnarhætti og öflugu eftirlitskerfi eru OR skapaðar forsendur til að annast starfsemi í págu almennings (Eigendastefna Orkuveitu Reykjavíkur, 2014; Guðrún Erla Jónsdóttir, 2015). Heildarstefna OR samstæðunnar byggir á lykilpáttum eigendastefnunnar sbr. mynd 2.

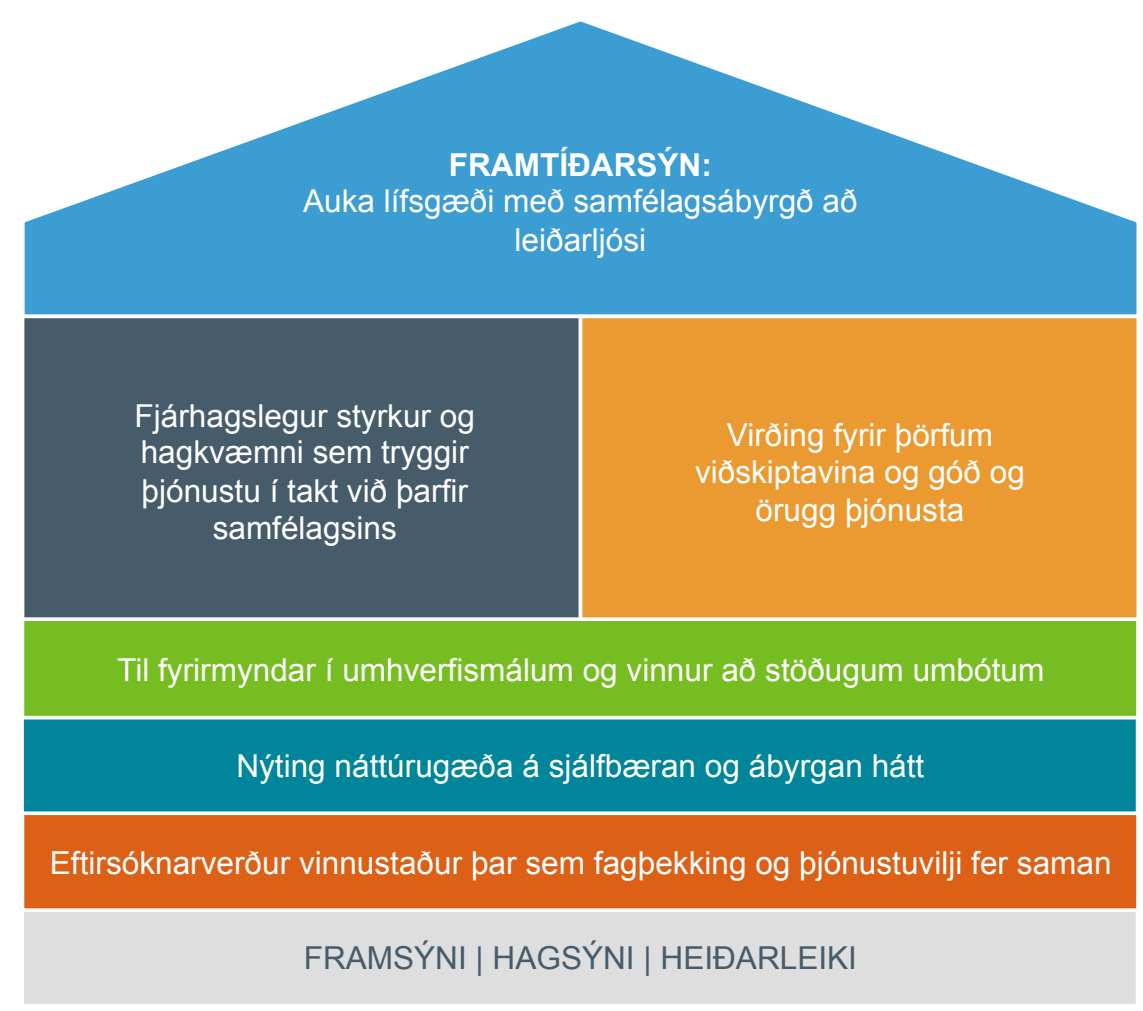

Mynd 2. Myndræn framsetning heildarstefnu OR 
Í eigendastefnu er stjórn OR meðal annars falið pað hlutverk að marka fyrirtækinu heildarstefnu og framtíðarsýn til samræmis við eigendastefnu auk pess að skilgreina lykilárangursmælikvarða. Stefnumótun í dótturfélögum skal samræmast stefnumótun móðurfélags og byggir stefnumótun í samstæðu OR á grunni gildanna framsýni, hagsýni og heiðarleika.

Dótturfélög og svið innan OR hafa einnig mótað sér sína stefnu varðandi pað hvernig pau uppfylla hlutverk sitt innan samstæðunnar. Í eigendastefnu segir einnig að stefnumótun stjórnar skuli taka til arðsstefnu, áhættustefnu, umhverfis- og auðlindastefnu, gæðastefnu, stefnu varðandi öryggis-, heilsu- og vinnuvernd, innkaupastefnu, upplýsingaöryggisstefnu, upplýsingatæknistefnu, starfsmannastefnu, starfskjarastefnu, jafnréttisstefnu og siðareglna (Eigendastefna Orkuveitu Reykjavíkur, 2014). Pessar stefnur skýra pað nánar hvernig samstæðan ætlar að vinna. Til að ná framtíðarsýninni er stuðst við pessar stefnur, sem flokkast sem lykilstefnur eða stuðningsstefnur hjá OR. Stefnumótun fyrir dótturfyrirtæki skal samræmast gildandi stefnu á hverjum tíma í pessum málaflokkum. Yfirlit yfir stefnuskjöl í samstæðu OR er á mynd 3 sem hér fylgir.

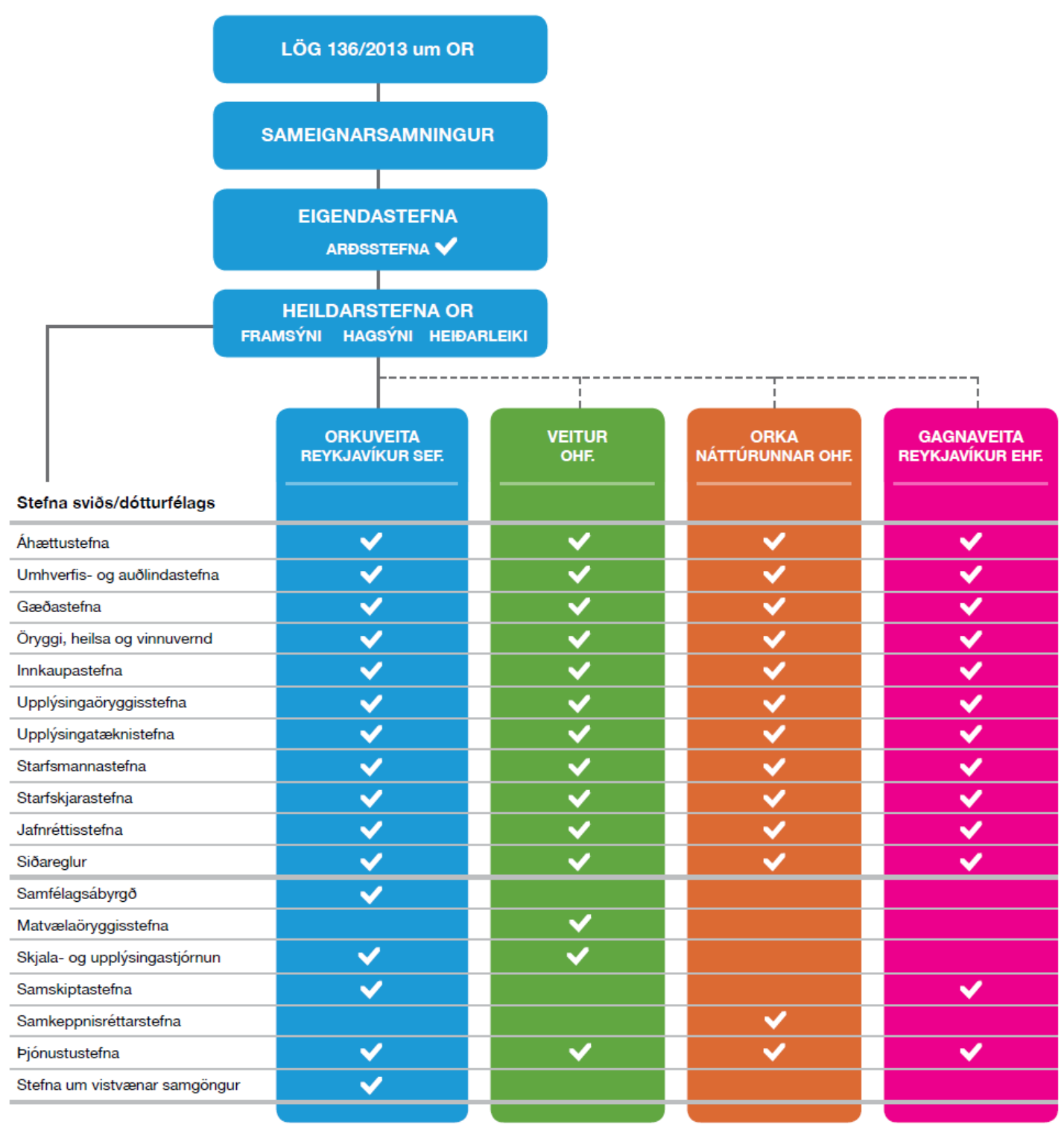

Mynd 3. Yfirlit yfir stefnuskjöl í samstæðu OR

Heimild: Guðrún Erla Jónsdóttir, 2017 


\section{3 Ábyrgð stjórnar OR}

Í sameignarsamningi er stjórn Orkuveitu Reykjavíkur (OR) falið að fara með málefni fyrirtækisins milli eigendafunda og hafa eftirlit með að stefna fyrirtækisins, skipulag pess og rekstur sé jafnan í réttu og góðu horfi og í samræmi við stefnu eigenda (Sameignarsamningur, 2014). Stjórn OR er skipuð sex einstaklingum. Par af eru fimm kjörnir af borgarstjórn Reykjavíkur og einn af bæjarstjórn Akraness. Sveitarstjórn Borgarbyggðar er heimilt að tilnefna áheyrnarfulltrúa með málfrelsi og tillögurétt (Sameignarsamningur, 2014). Til að stjórn OR geti haft eftirlit með að stefna móðurfélags og eigenda endurspeglist í heildarstefnu dótturfélaga fær hún par til bærar upplýsingar frá stjórnum dótturfélaganna. Stefnumörkun í dótturfélögum er rædd af hálfu stjórnar móðurfélags til að tryggja samræmi við heildarstefnu samstæðunnar og stefnu eigenda (Guðrún Erla Jónsdóttir, 2015). Hlutverk stjórnar móðurfélags er að sameina hagsmuni samstæðunnar og hagsmunaaðila út frá lögum, sameignarsamningi og eigendastefnu, útfæra stefnu og markmið til samræmis og veita stjórnendum fyrirtækisins stuðning og aðhald (Guðrún Erla Jónsdóttir, 2015).

Stjórn móðurfélags OR hefur lagt ríka áherslu á að koma á fyrirkomulagi sem tryggir framfylgd eigendastefnu, heildarstefnu og stefnu peirra málaflokka sem eigendastefna tilgreinir auk pess að styðja við pað að stefnur dótturfélaga samræmist stefnumótun móðurfélags. Stefnumótun hefur verið skilgreind sem málaflokkur innan samstæðunnar og fer stefnustjóri (e. strategy officer) með umsjón hans. Stefnumótun, líkt og önnur stoðsvið, gengur pvert á svið og dótturfélög samstæðunnar og hefur pað hlutverk að styðja við stefnumótun, innleiðingu stefnu og tryggja samræmingu í samstæðu OR. Stefnustjóri styður á pann hátt við framfylgd eigendastefnu OR og er fjallað um pað næst með hvaða hætti pað er gert.

\subsection{Verklag við mótun og eftirfylgni stefnu hjá OR}

Próað hefur verið verklag fyrir stefnutengt starf innan samstæðu OR sem er aðlagað starfseminni og er í stöðugri endurskoðun. Aðgerðaráætlun fyrir stefnu hjá samstæðu OR er kölluð stefnuáætlun og er hún unnin fyrir hvert ár. Stefnuáætlun felur í sér yfirlit yfir stefnuverkefni, tímasettar aðgerðir eða verkefni, sem vinna skal að á árinu. Haldið er utan um öll stefnuverkefni í svonefndu stefnubókhaldi, kerfi sem er hýst á veraldarvefnum og hefur pann tilgang að gera stórum sem smáum fyrirtækjum kleift að halda utan um verkefni og framvindu peirra.

\subsubsection{Innviðir og rýni stefnu}

Hjá samstæðu OR hefur verið komið á fót tilteknu verkferli sem tryggir vöktun, rýni og endurmat stefnu. Kjarninn í pví stjórnkerfi er Stefnuráð í samstæðu OR. Hlutverk og ábyrgð Stefnuráđs er prípætt. Í fyrsta lagi að móta, rýna og vakta sameiginlegar stefnur í samstæðu OR. Í öðru lagi að rýna markmið og (lykil)mælikvarða og í priðja lagi að fjalla um stefnuverkefni (Guðrún Erla Jónsdóttir, 2016). Stefnuverkefni eru pau verkefni sem miða að pví að innleiða tiltekna stefnu. Stefnuráð er skipað af forstjóra OR. Í Stefnuráði sitja forstjóri, framkvæmdastjórar í samstæðu OR og yfirmaður lögfræðimála. Starfsmenn Stefnuráðs eru stefnustjóri og stjórnandi pess málaflokks sem er til umfjöllunar hverju sinni samkvæmt starfsáætlun Stefnuráðs, par sem hver og ein gildandi stefna í móðurfélagi OR er tekin til rýni að lágmarki árlega. Með pessu móti er leitast við að tryggja að sérhver stefna í móðurfélaginu sé rýnd reglulega ásamt markmiðum og mælikvörðum auk pess sem farið er yfir pað hvernig fyrirhugað er að vinna að framkvæmd hennar í samstæðunni (innleiðing).

Stjórnanda málaflokks ber að undirbúa rýni stefnu með pví að styðjast við tiltekinn staðal pegar pað á við og jafnframt umfjöllun um stefnu, tillögu að breytingum á henni ef með parf, rýni markmiða og (lykil)mælikvarða og umfjöllun um stefnuverkefni. Rýni sem stjórnandi málaflokks undirbýr fer fyrir Stefnuráð til umfjöllunar. Að pví loknu fara stefnur sem tilgreindar eru í eigendastefnu OR til sampykktar hjá stjórn móðurfélags. Áhættustefna og arðsstefna fara jafnframt til sampykktar eigenda. İ stjórn er stefnan (rýni 
stefnunnar) kynnt og tekin til umræðu, ásamt markmiðum hennar og mælikvarða. Bein athugun rannsakenda leiddi í ljós að stjórn OR tekur oft virkan pátt í umræðu um stefnu, sem hefur leitt til breytinga frá peirri tillögu sem lá fyrir fundinum. Pannig hefur stjórn OR tækifæri til aðkomu að stefnumótunarferlinu.

Aðrar stefnur en pær sem eigendastefna tilgreinir eru afgreiddar í Stefnuráði og aðeins sumar peirra koma inn á borð stjórnar OR. Framkvæmdastjórar dótturfélaga bera ábyrgð á pví að rýna viðkomandi stefnu, hver í sínu félagi, með tilliti til breytinganna og leggja eftir atvikum breytta stefnu sem tilgreind er í sampykktum stjórnar dótturfélagsins til sampykktar hjá stjórn viðkomandi dótturfélags. Stjórnandi málaflokks leiðir einnig rýni stefnunnar í dótturfélagi, tryggir samræmingu stefnumótunar í móðurfélagi og dótturfélagi og styður stjórnendur við innleiðingu stefnunnar. Heildarstefna hvers dótturfélags er á ábyrgð hverrar stjórnar samkvæmt sampykktum en skal pó ávallt samræmast stefnumótun í málaflokkum og heildarstefnu móðurfélags OR, samanber áherslur í eigendastefnu OR. Eftirfarandi mynd 4 lýsir verklagi við rýni stefnu í samstæðu OR:

\begin{tabular}{|c|c|c|c|c|c|}
\hline $\begin{array}{l}\text { Stjórnandi } \\
\text { málaflokks }\end{array}$ & $\begin{array}{l}\text { Nefnd/vinnu- } \\
\text { hópur }\end{array}$ & $\begin{array}{l}\text { Rýni og } \\
\text { umfjöllun }\end{array}$ & Stefnuráð & Stjórn OR & $\begin{array}{c}\text { Rýni } \\
\text { framkvæmda- } \\
\text { stjóra } \\
\text { dótturfélaga }\end{array}$ \\
\hline $\begin{array}{l}\text { Stjórnandi } \\
\text { málaflokks ber } \\
\text { ábyrgð á rýni } \\
\text { stefnu og fær til } \\
\text { liðs við sig pá sem } \\
\text { hann telur } \\
\text { mikilvæga við rýni }\end{array}$ & $\begin{array}{l}\text { Starfsnefndir/ } \\
\text { vinnuhópar miðla } \\
\text { upplýsingum til } \\
\text { stjórnanda } \\
\text { málaflokks }\end{array}$ & $\begin{array}{l}\text { Stjórnandi } \\
\text { málaflokks } \\
\text { undirbýr rýni } \\
\text { stefnu, markmiða } \\
\text { og lykilárangurs- } \\
\text { mælikvarða }\end{array}$ & $\begin{array}{l}\text { Umfjöllun um } \\
\text { stefnur til } \\
\text { samræmis við } \\
\text { starfsáætlun }\end{array}$ & $\begin{array}{l}\text { Stjórn tekur til } \\
\text { umfjöllunar og } \\
\text { afgreiðslu } \\
\text { stefnur sem } \\
\text { tilgreindar eru í } \\
\text { eigendastefnu } \\
\text { ásamt } \\
\text { markmiðum og } \\
\text { mælikvörðum }\end{array}$ & $\begin{array}{l}\text { Framkvæmdastjórar } \\
\text { og ábyrgðarmaður } \\
\text { stefnu rýna í } \\
\text { sameiningu stefnu } \\
\text { dótturfélags og } \\
\text { leggja fyrir stjórn } \\
\text { pess til umfjöllunar } \\
\text { og afgreiðslu }\end{array}$ \\
\hline
\end{tabular}

Mynd 4. Verklag við reglubundna rýni á stefnu, markmiðum og mælikvörðum í samstæðu OR Heimild: Orkuveita Reykjavíkur, 2017.

\subsubsection{Vegferoin-stefnuverkefnum hrint í framkvæmd}

pegar búið er að rýna stefnu, markmið og mælikvarða er næsta skref að vinna að verkefnum sem miða að innleiðingu stefnunnar. Stefnur í samstæðu OR eru alla jafna orðaðar á knappan og hnitmiðaðan hátt, pær eru áfangalausar og tímalausar og markmið og mælikvarðar eru ekki orðuð í stefnuskjalinu sjálfu. Haldið er utan um markmið og mælikvarða á sérstökum mælikvarðablöðum.

Stefnu fylgir svokölluð stefnuáætlun sem inniheldur yfirlit yfir stefnuverkefni. Verklag við innleiðingu stefnu má setja fram myndrænt eins og gert er á mynd 5. Framkvæmdastjórar og forstöðumenn yfirfara árlega stefnu og áherslur fyrir næsta ár. Pá er farið yfir markmið sviðs eða dótturfélags fyrir næsta ár og áherslur ákveðnar. Petta er undanfari vals á stefnuverkefnum, sem eru verkefni sem miða að innleiðingu stefnu. Stefnuáætlanir eru kynntar öllum í skipuriti samstæðunnar og verkefnaskilgreiningum (stefnupristum) er skilað til stefnustjóra pegar verkefni hefjast. Ábyrgð allra í skipuriti á stefnumótun, innleiðingu og eftirfylgni auk miðlunar upplýsinga til allra teyma samstæðunnar er skilgreind í rekstrarhandbókarskjölum.

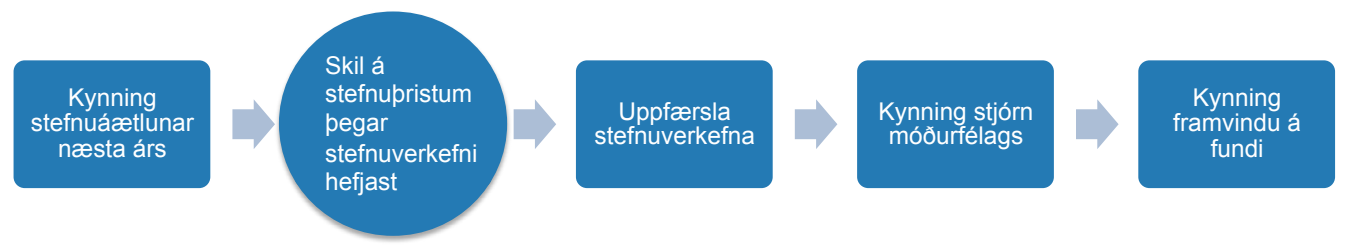

Mynd 5. Verklag við innleiðingu á stefnu í samstæðu OR

Heimild: Orkuveita Reykjavíkur, 2017. 
Stefnustjóri heldur utan um öll stefnuverkefni í stefnubókhaldi par sem ábyrgðarmenn verkefnanna uppfæra framvindu peirra. Upplýsingagjöf til stjórnar móðurfélags og stjórnenda í samstæðunni er annan hvern mánuð. Með pessu móti er fylgst sameiginlega með pví að áætlun um innleiðingu stefnu sé gerð, að unnið sé að verkefnum sem hrinda stefnu í framkvæmd og markmiðum sé náð. Auk pess er upplýsingum um árangur miðlað.

\subsection{Samstilling og samheldni um stefnu OR}

Eftir uppskiptingu OR var lögð áhersla á að ýta undir samheldni um heildarstefnu OR sem mótuð var út frá eigendastefnu félagsins. Til pess að koma til móts við pað hefur verið unnið að pví innan allra eininga samstæðunnar að samstilla stefnu og starfsfólk. Раð hefur verið gert með pví að tefla fram sameiginlegum grunngildum OR sem eru framsýni hagsýni og heiðarleiki, sbr. mynd 3 í kafla 4.2. Einnig hefur verið stuðlað að sameiginlegum skilningi á stefnu innan OR með sérstakri handbók samstæðunnar, OR bókinni, sem hefur pann tilgang að styðja starfsfólk í daglegum störfum og útskýra hvar fyrirtækið er og hvert pað stefnir. Hjá OR er litið pannig á að pað sé sama við hvað starfsfólk vinnur í samstæðunni, hver og einn leggi sitt af mörkum til stefnunnar og pví sé pað mikilvægt að allir hafi sameiginlega sýn. Fram kemur í gögnum að frammistaða samstæðunnar ráðist af samvinnu dótturfélaga og móðurfélags og pá skipti máli að samstæðan sé samstillt og sameiginlegur skilningur sé á hlutverki og stefnu (Guðrún Erla Jónsdóttir, 2017).

Forstjóri samstæðu OR hefur lagt á pað ríka áherslu að miðla upplýsingum til alls starfsfólks gegnum „Samtalið“ sem er fundaröð með öllu starfsfólki samstæðunnar (viðtal við stjórnanda hjá OR), um 18 manns í einu, par sem hann hefur farið yfir stöðu fyrirtækisins fyrir og eftir uppskiptingu, gildi samstæðunnar, stefnu og fleira auk pess að gefa öllu starfsfólki kost á að spyrja spurninga. Pá eru einnig reglubundnir stjórnendafundir innan samstæðunnar par sem meðal annars er farið yfir breytingar á stefnum, markmiðum og mælikvörðum auk pess sem greint er frá árangri stefnuverkefna. Pví til viðbótar eru reglubundnir starfsmannafundir allra sviða og par eru stefnur ræddar, hvort markmiðum hafi verið náð og teknar ákvarðanir um frávik.

\section{Stefnumiðaðir stjórnarhættir - lærdómur af raundæmi}

Eins og tilgreint var í inngangi er markmiðið með greininni að skila framlagi til pekkingar á pví hvernig stefnumiðaðir stjórnarhættir og sérstaklega eigendastefna gerir stjórnum fyrirtækja og stofnana kleift að rækja skyldur sínar við pað að fylgja eftir vilja og markmiðum eigenda og stuðla að pví að pær skipulagsheildir sem eiga í hlut séu í góðum takti við réttmætar óskir og væntingar hagsmunaaðila.

Í fræðihluta hefur verið fjallað ítarlega um fyrirbærið og hugtakið stjórnarhætti. Túlkun höfunda er að stjórnarhættir snúist um pekkingu á pví hvernig staðið sé að skilgreiningu umboðs stjórnenda fyrirtækja og stofnana og peim verði veitt leiðsögn og aðhald til pess аð stuðla að pví að fyrirliggjandi auðlindir séu nýttar með ábyrgum hætti eigendum, öðrum hagsmunaaðilum og samfélaginu í heild til heilla. Stjórnarhættir ná pannig utan um hvernig farið er með yfirráð yfir skipulagsheildum, hvernig skuli haga samspili og samskiptum peirra við umhverfið í víðum skilningi og hvernig megi á skipulegan hátt styðja við inntak og árangur af starfsemi peirra.

Viðfangsefnið er afmarkað við stefnutengt hlutverk stjórnarhátta sem einkum er á ábyrgðarsviði stjórnar fyrirtækis og stjórnarmanna pess (Bezemer, Nicholson og Pugliese, 2018; Bonn og Pettigrew, 2009). Stefnutengt hlutverk stjórna hefur verið dregið saman í eitt hugtak, stefnumiðaða stjórnarhætti, sem hér hefur verið skilgreint sem pað afmarkaða hlutverk stjórna sem snýr að virkri pátttöku í stefnumiðaðri stjórnun peirra fyrirtækja og stofnana sem viðkomandi stjórn ber ábyrgð á. Rýni á fræðilegum heimildum um hið stefnutengda hlutverk hefur varpað ljósi á hvað við er átt með pessu hlutverki og er mögulegt að spegla pað við niðurstöður rannsóknarinnar á pví hvernig OR hefur farið að í pessu efni. Hin fræðilega umfjöllun ber líka með sér að pað vanti pekkingu á pessu sviði 
og pað er von höfunda að rannsóknin á pví hvernig pessum málum er hagað í Orkuveitu Reykjavíkur skili áhugaverðu framlagi, bæði til aukinnar pekkingar á stefnumiðuðum stjórnarháttum en líka að útfærslan á vinnulagi og ferli OR á pessu sviði geti haft hagnýta pýðingu fyrir aðrar skipulagsheildir.

Til að rýna í stefnumiðaða stjórnarhætti út frá dæminu um samstæðu OR var sett fram eftirfarandi rannsóknarspurning:

Hvernig má vinna að framkvæmd formlegrar eigendastefnu og stuðla að stefnumiðuðum stjórnarháttum?

Til að svara pessari rannsóknarspurningu verður farið skipulega yfir niðurstöður rannsóknarinnar sem settar voru fram í kaflanum hér að framan. Úrvinnsla tekur líka mið af peirri aðferðafræði sem stuðst var við í rannsókninni. Um er að ræða raundæmisrannsókn á könnunarstigi (e. explorative case study) á einu dæmi sem skoðað er heildrænt. Pessi aðferð gerir mögulegt að draga fram lærdóm út frá peim gögnum sem rannsökuð eru.

Úrvinnslu og umræðu um niðurstöður er samkvæmt pví skipt upp í eftirfarandi efnisatriði: a) Skipulagslegar áskoranir sem OR og stjórn standa frammi fyrir; b) Mótun stefnu með samstilltum hætti; c) Markmið og inntak eigendastefnu; d) Ábyrgð stjórnar; e) Verklag við ferli stefnumótunar og eftirlit með framvindu stefnu; f) Samantekt. Verður nú hvert af pessum atriðum tekið fyrir og fjallað um pau.

\section{a) Skipulagslegar áskoranir sem OR og stjórn standa frammi fyrir}

Niðurstöðurnar draga fram tvö megin tilefni til breytinga á vinnubrögðum stjórnar OR. Par má fyrst nefna viðbrögð við gagnrýni á stjórnarhætti fyrirtækisins sem kom fram í kjölfar efnahagshrunsins 2008, en pá stóð OR mjög illa eftir miklar fjárfestingar. Samkvæmt úttekt óháðrar úttektarnefndar á stjórnun fyrirtækisins í aðdraganda hrunsins komu fram fjölmörg dæmi um óljós valdmörk stjórnenda og ófullnægjandi eftirlit af hálfu stjórnar. Petta leiddi til ákvarðana sem fólu í sér óhóflega áhættu og voru ekki í takti við kjarnahlutverk (Margrét Pétursdóttir o.fl., 2012). Af skýrslu úttektarnefndarinnar má almennt draga pá ályktun að OR hafi staðið frammi fyrir miklum áskorunum er varða grundvallaratriði í starfseminni.

Í kafla 4.1. var fjallað um pær skyldur sem fylgdu breytingum á raforkulögum og m.a. höfðu í för með sér kröfu um aðskilnað í starfsemi OR. Fram kom í niðurstöðum rannsóknarinnar að uppskiptingu OR hafi ítrekað verið frestað. Breytingar á raforkulögum sem mæltu fyrir um aðskilnað á milli framleiðslu og sölu rafmagns annars vegar og dreifingar hins vegar tóku gildi árið 2008. Upphaflega átti lagaákvæðið að ganga í gildi 1. júlí 2009. en uppskipting fyrirtækisins kom ekki til framkvæmda fyrr en í janúar 2014. Pá tók við samstæðuskipulag sem krefst annars konar og um margt flóknari nálgunar í stjórnun og stjórnarháttum en fyrra skipulag fyrirtækisins. Eftir uppskiptingu eru dótturfélögin prjú, p.e. Veitur ohf., Orka náttúrunnar ohf. og Gagnaveitan ehf., og eru hvert með sína stjórn sem starfar samkvæmt lögum um viðkomandi hlutafélög og er skapað sjálfstæði í störfum. Samkvæmt skipuritinu sem birt er í mynd 1 í kaflanum hér að framan, er leitast við að tryggja tengslin á milli OR sem móðurfélags og dótturfélaganna með tvípættum hætti. Annars vegar gegnum forstjóra sem samkvæmt skipuritinu fer með eigendavald á aðalfundum dótturfélaganna og hins vegar gegnum stoðpjónustu sem móðurfélagið veitir dótturfélögunum.

Niðurstöður raunrannsóknarinnar bera með sér að mikilvægt sé að leggja ríka áherslu á að tryggja samstillingu á milli stjórna dótturfélaga og stjórnar móðurfélagsins, bæði gegnum samstæðuskipulagið og með samstilltri vinnu í tengslum við rýni, mótun og eftirfylgni með framkvæmd stefnu hjá OR. Samkvæmt viðmælendum var allt kapp lagt á að prátt fyrir uppskiptingu mundi OR starfa sem ein heild með samhæfða stefnu út frá fyrir- 
liggjandi eigendastefnu. Niðurstöður rannsóknarinnar sýna að OR vinnur með virkum hætti að pessu með skilgreindu samspili á milli eigendastefnu, heildarstefnu og fjölda annarra stefnuskjala, sbr. myndir 2 og 3 í kaflanum hér að framan. Dæmið um OR bendir til að verulegar áskoranir geti verið tengdar pví að ráðast í innleiðingu samræmdra stjórnarhátta í samstæðuskipulagi út frá einni sameiginlegri eigendastefnu samstæðunnar.

Sé litið til OR má segja að fyrirtækið hafi vegna lagaboðs horfið frá blönduðu skipulagi undir einni stjórn par sem afurðaskipting hafi verið megineinkennið, yfir í pað sem hér er nefnt samstæðuskipulag, sem í raun er áfram blandað skipulag; nú undir stjórn priggja stjórna auk stjórnar móðurfélagsins. Um leið er haldið uppi pjónustu stoðdeilda fyrir öll dótturfélög pótt tengingin við rekstrareiningar sé ekki lengur gegnum valdbraut forstjóra heldur eignarhald móðurfélags og tengsl forstjóra við stjórnir dótturfélaga sem handhafa eigendavalds móðurfélagsins. Hér er horfið frá pví sem kalla má óslitna umboðskeðju frá stjórn til forstjóra og paðan til stjórnenda, til umboðskeðju par sem inn á milli koma sjálfstæðar stjórnir. Hverri stjórn ber að hafa hagsmuni viðkomandi fyrirtækis að leiðarljósi en lýtur ekki beinu valdi stjórnar móðurfélagsins og forstjóra pess í umboði stjórnar nema að pví er varðar að virða hagsmuni og óskir eigenda um tiltekinn árangur í rekstri og ákvæði um að starf dótturfélaganna skuli vera í takti við eigendastefnu og heildarstefnu OR.

Petta dæmi undirstrikar mikilvægi pess að stefnumiðaðir stjórnarhættir feli í sér formlegt og samræmt stefnumiðað starf um alla pá skipulagsheild sem á í hlut með útgangspunkt í heildrænni eigendastefnu. Stefnumiðaðir stjórnarhættir fela einnig í sér að unnið er með ákveðnum og samræmdum hætti að rýni, mótun stefnu og eftirliti með framvindu og próun skipulagsheildarinnar. Hversu mikil áskorun petta er fyrir stjórn OR má sjá í ljósi kenninga um skipulag fyrirtækja, par sem bent er á að afurðaskipulag sé flókið, en samræming gegnum samstæðu- og eignarhaldsskipulag er ennpá flóknara stjórnunarverkefni (Runólfur Smári Steinpórsson o.fl., 2018)

\section{b) Mótun stefnu með samstilltum hætti}

Fram kemur í raunrannsókninni að bæði sameignarsamningur og eigendastefna OR hafi verið endurskoðuð árið 2014 við uppskiptingu fyrirtækisins, en rannsóknin leiðir í ljós að verkefnið við mótun núverandi eigendastefnu hafi hafist árið 2010 og pví hafi verið lokið árið 2012. Pannig má sjá að vinnan við mótun eigendastefnu hafi ekki síður verið viðbragð við stöðu OR eftir hrunið, en bein afleiðing af ákvæðum sameignarsamningsins. Rannsóknin sýnir einnig að eigendastefnan hafi verið mótuð og unnin í samstillingu við aðra stefnumótun innan OR, p.e. mótun heildarstefnu, stefnu málaflokka, stefnu sviða og dótturfélaga. Lagskipting og fjölbreytni í stefnuskjölum kemur heim og saman við pað sem Mintzberg o.fl. (1998), Chaffee (1985) auk Johnson o.fl. (2008) segja um mismunandi stefnur sem purfa stöðugt að vera í endurskoðun. Pessar fræðilegu heimildir benda jafnframt á að stefnumiðað starf er ekki alltaf kerfisbundið eða línulegt jafnvel pótt framsetningin sé á pann veg. Innan fyrirtækja og stofnana er stefnumiðað starf viðvarandi verkefni (Runólfur Smári Steinpórsson, 2003a) og framvinda stefnumiðaðs starfs getur annað hvort eða bæði verið í takti við rökrænt ferli eða sjálfsprottið og ófyrirséð ferli (Runólfur Smári Steinpórsson, 2003b).

Raunrannsóknin varpar ljósi á stefnumótun í samstæðu sem samanstendur af móðurfélagi og sjálfstæðum dótturfélögum par sem lagt er kapp á að stjórnir og stjórnendur allra félaga séu samtaka og samstillt í ferlinu við rýni, mótun og framkvæmd stefnu. Viðtöl við stjórnendur leiða í ljós, að pað sem felur í sér eina stærstu áskorunina í pessu efni er að tryggja að allir lykilaðilar í pessari keðju axli ábyrgðina sem að peim snýr. Í pví efni hefur bein athugun rannsakenda leitt í ljós, að eitt er að setja fram vel útfært verklag stefnumótunar með tilheyrandi ferlum og skilgreiningum, en annað er að fá fram samstöðu um að vinna eftir pví pannig að samfella skapist í mótun og eftirfylgni stefnu út frá sameiginlegri eigendastefnu. Samkvæmt viðtölum við stjórnendur hefur komið í ljós að verkefnið 
er álitið mis mikilvægt og tíma hefur tekið að fá alla hlutaðeigandi til pess að viðurkenna mikilvægi starfs af pessu tagi. Í daglegu amstri getur reynst erfitt að finna tíma til að horfa fram á veginn á skipulegan hátt. Pegar mikið er aðkallandi í rekstrinum er hætt við að peim sem ábyrgð bera á daglegum rekstri finnist verkefni af pessu tagi flókin, viðamikil og jafnvel til ópurftar. Pannig hefur pað komið fram, að sumir álíti pátttöku í að framfylgja samræmdum stefnumiðuðum stjórnarháttum eins og hér hefur verið lýst, réttlætanlega af peirri ástæðu einni að peim er gert skylt „ofan frá“ að taka pátt.

Á sama tíma hefur komið í ljós, að innleiðingin krefst viðvarandi og reglulegs starfs, einkum fyrstu árin, til pess að tryggja að verklagið og viðurkenning á mikilvægi pess verði inngreypt í menningu allra hluta samstæðunnar. Veikleikarnir birtast pví einkum í pví, að úthald er mögulega ekki nægilegt til pess að komast yfir fyrsta pröskuldinn. Innan OR er enn pað stutt síðan skipuleg innleiðing á stefnumiðuðum stjórnarháttum hófst, að eftirfylgni er enn með fullum punga, og tekið er á nauðsynlegum breytingum sem geta verið til bóta í ferlinu, en á vegferðinni hafa pessar áskoranir vissulega komið fram.

Pau atriði sem fjallað er um í næstu köflum hér á eftir, hafa um margt verið til pess fallin að koma til móts við pær áskoranir sem felast í peirri breytingu á atferli og menningu sem nauðsynleg er til pess að raungera stefnumiðaða stjórnarhætti í allri samstæðunni.

\section{c) Markmið og inntak eigendastefnu}

Varðandi mótun stefnu pá kemur fram í sameignarsamningi að eigendur skuli marka fyrirtækinu og dótturfélögum stefnu. Í eigendastefnu kemur svo fram að stjórn OR skuli leggja fram fyrir eigendafund rökstudda tillögu að heildarstefnu og stefnu í tilgreindum málaflokkum. Í 6. grein eigendastefnunnar segir jafnframt að stefnumörkun fyrir dótturfélög skuli samræmast gildandi stefnu OR á hverjum tíma í hverjum málaflokki (Eigendastefna Orkuveitu Reykjavíkur, 2014).

Pótt rannsóknin sem hér er byggt á hafi verið afmörkuð við tímann frá pví eftir hrunið árið 2008 er rétt að geta pess að OR hefur gegnum árin hagnýtt aðferðir stjórnunar og stefnumótunar. Dæmi um pað er rekstrarhandbók félagsins sem á sér langa sögu (Margrét Pétursdóttir o.fl., 2012). Varðandi stjórnarhætti pá var Orkuveitan byrjuð að afla sér pekkingar á pessu sviði fyrir hrun en staða OR eftir hrunið og sú gagnrýni sem félagið fékk varð til pess að skerpt var enn frekar á stjórnarháttum (viðtal við stjórnanda hjá OR). Mótun og sampykkt eigendastefnu er eitt af pví sem ráðist var í eins og fram er komið. Virk eigendastefna er leið sem eigendur OR hafa til að takmarka eða fyrirbyggja umboðsvanda sem felst í pví að eigendur og stjórnendur geti haft markmið sem stangast á (Fama og Jensen, 1983; Jensen og Meckling, 1976). Með pví að vera virkari eigendur myndast aðhald og í framhaldinu umræða ef eigendur eru ekki samstiga.

Ef litið er á sjálft stefnuskjalið (sjá or.is) er gerð grein fyrir markmiðum pess í kaflanum Um eigendastefnuna. Síðan er skjalið í 8 tölusettum liðum par sem settar eru fram afmarkanir á eftirfarandi atriðum: leiðarljós, hlutverk, kjarnastarfsemi, starfssvæði, stjórnarhættir, stefnumótun, samskipti og upplýsingagjöf og ákvarðanir sem hljóta skulu sampykki eigenda. Í kaflanum um stefnumótun er líka kveðið á um fjárhagsleg markmið, áhættu í rekstri, umhverfi og auðlindanýtingu og starfskjör (Eigendastefna Orkuveitu Reykjavíkur, 2014).

Pess ber að geta að við leit á fræðilegum heimildum um stjórnarhætti og stefnumiðaða stjórnarhætti var sérstaklega litið eftir heimildum um rannsóknir á mótun og innleiðingu á eigendastefnu, en án árangurs. Fram kemur í niðurstöðum að mótun eigendastefnu hafi verið unnin samhliða mótun heildarstefnu og stefnu ýmissa málaflokka, auk mótunar stefnu fyrir dótturfélögin. Рað má skilja pannig að pegar á stigi mótunar stefnu pá hafi bæði samspil og samstilling milli stefnu fyrir málaflokka og einingar átt sér stað. Pegar litið er til fræðanna kemur pað ekki á óvart pví við stefnumótun er jafnan tekið mið af „peim raunveruleika sem við er að glíma hverju sinni“ (Runólfur Smári Steinpórsson, 
2003a, bls. 49). Verklag við stefnumótun innan samstæðu OR hefur verið lagað að starfseminni og er í stöðugri endurskoðun, sbr. umfjöllun um verklag við rýni, mótun og framkvæmd stefnu OR.

\section{d) Ábyrgð stjórnar}

Kveðið er skýrt á um hlutverk stjórnar OR í sameignarsamningi og eigendastefnu OR. Framsetningin á hlutverki stjórnar virðist vera í ágætum takti við góða stjórnarhætti og eigendastefnan kveður á um að stjórnarhættir OR eigi að tryggja fagmennsku, hagkvæmni, ráðdeild, gegnsæi og ábyrgð í rekstrinum. Pannig má segja að stjórn OR hafi fengið vegvísi, ábyrgð og umboð frá eigendum til að halda utan um samstæðu OR með tilgreindum valdmörkum (Gnan o.fl., 2011). Eigendastefnan felur pað líka í sér að stjórnin má gera ráð fyrir pví að eigendur OR verði virkir gegnum reglulega eigendafundi. Rannsóknin gefur pannig vísbendingu um að stjórn OR hafi allar forsendur til að tileinka sér vinnubrögð sem eru lýsandi fyrir góða stjórnarhætti (Thomsen, 2008; Viðskiptaráð o.fl., 2009) og hún geti par með uppfyllt ábyrgðarhlutverk sitt (Solomon og Solomon, 2004). Uppskipting OR var hins vegar mikil áskorun og pví purfti að finna leið til að útfæra valddreifingu og umboð út frá stefnu og markmiðum eigenda.

Prátt fyrir að skýrt sé kveðið á um hlutverk stjórnar móðurfélagsins pýðir núverandi samstæðuskipulag að stjórn hefur ekki beint boðvald yfir stjórnum dótturfélaga, hvorki samkvæmt lögum né peim almennu viðmiðum um stjórnarhætti sem í gildi eru. Pannig verður um margt flóknara fyrir stjórn móðurfélags að gegna hlutverki sínu og skyldum í samræmi við eigendastefnu og sameignarsamning. Stefnumiðaðir stjórnarhættir eins og hér hefur verið lýst, eru beinlínis nauðsynlegir til pess að tryggja að yfirstjórn samstæðunnar í heild hafi vægi og hlutverk gagnvart einingum hennar. Til pess að koma til móts við pennan umboðsvanda var áskilið í sampykktum allra dótturfélaga að pau skyldu innleiða stefnu í öllum sömu málaflokkum og móðurfélagið og að pær skuli samræmast gildandi stefnum OR. Að auki hefur pessi staða stjórnar móðurfélags kallað fram mikla próun í starfsháttum sem lúta að mótun stefnu sem gildir fyrir samstæðuna í heild og að hafa yfirsýn og eftirlit með pví að eftir henni sé farið.

\section{e) Verklag við ferli og framvindu stefnu}

Pegar rýnt var í fyrirliggjandi pekkingu á pví hvernig stjórnir eru að sinna stefnutengdu hlutverki, sbr. umræðu í fræðikafla greinarinnar, kom í ljós að pekking er af skornum skammti og kallað er eftir frekari rannsóknum (Bonn og Pettigrew, 2009; Brauer og Schmidt, 2007; Fiegener, 2005; Hendry og Kiel, 2004; Pugliese o.fl., 2009; Runólfur Smári Steinpórsson, 2017).

Rannsóknin á OR, sem dæmi, sýnir að fyrirtækið hefur farið pá leið að koma sér upp tilteknu skipulagi og ákveðnu verklagi til að halda utan um ferli og framvindu stefnu í fyrirtækinu pvert á einingar og málaflokka. Lykilhugtök hafa verið skilgreind og hlutverk helstu lykilaðila eða gerenda í ferlinu hafa einnig verið skilgreind. Helstu hugtök eru stefna, stefnuáætlun, stefnuverkefni, verkefnaskilgreiningar (stefnupristar), markmið og (lykil)mælikvarðar, auk stefnubókhalds. Helstu lykilaðilar eru Stefnuráð, stefnustjóri, stjórnandi málaflokks, starfsnefnd, vinnuhópur, framkvæmdastjórar, forstjóri, stjórn dótturfélags, stjórn OR og eigendafundur. Í kaflanum um niðurstöður raunrannsóknarinnar er í mynd 4 og 5 lýst nánar hvernig verklagi OR er háttað í tengslum við ferli og framvindu stefnu.

Eigendastefna OR er mjög ítarlegt stefnuskjal par sem sett er fram leiðarljós, hlutverk og afmörkun á bæði kjarnastarfsemi og starfssvæði OR. Stjórn OR hefur pað hlutverk að sjá til pess að starfsemi OR sé í góðum takti við eigendastefnuna. Stjórninni ber að leggja fram tillögu að heildarstefnu og framtíðarsýn OR, auk stefnu í tilgreindum málaflokkum. 
Stefnumörkun fyrir dótturfyrirtæki er á ábyrgð stjórna peirra, en skal á hverjum tíma vera í samræmi við pað sem er stefna OR á hverjum tíma. Eigendastefna OR er skýr vegvísir og pað verklag sem OR hefur próað er skilgreindur farvegur fyrir rýni, mótun og eftirlit með framkvæmd stefnu. Pað má jafnframt sjá á verklagi OR að lykilaðilar eru um allt fyrirtækið á öllum prepum í skipulagi pess og í öllum einingum.

Útfærslan á verklagi OR, skv. myndum 4 og 5, dregur ekki fram sérstaklega pá verkaskiptingu og pau valdmörk sem eru á milli eigenda, stjórnar OR, forstjóra, stjórna dótturfélaga og stjórnenda peirra. Pað eru tiltekin atriði í verklaginu sem lýsa aðkomu stjórnar og pau atriði eru skilgreind sem rammi fyrir beina stefnumiðaða stjórnarhætti. Svo eru atriði sem óbeint tengjast verkefnum stjórnar OR varðandi pað hvernig samstæðan undir forystu forstjóra og annarra lykilaðila vinnur með stefnutengd verkefni, bæði til undirbúnings á pví að stefna og stefnutengd verkefni eru lögð fyrir stjórn OR og við úrvinnslu og framkvæmd stefnu eftir umfjöllun stjórnar OR. Dæmið um ferli og framvindu stefnu hjá OR sýnir að lagt er upp úr pví að hafa ferlið samstillt og jafnframt er starfandi sérstakur aðili, stefnustjóri, sem fer með samræmingarhlutverk.

Af raundæminu um OR má ráđa að verklag fyrirtækisins feli í sér bæði beina og óbeina stefnumiðaða stjórnarhætti sem miði að pví að tryggja pað að stefna ólíkra sjálfstæðra eininga innan fyrirtækjasamstæðu samræmist yfirlýstum áherslum OR og kallist á við heildarstefnu samstæðunnar. Fyrrgreindir stefnumiðaðir stjórnarhættir stuðla einnig að pví að unnið sé í takti við eigendastefnu, að stjórn taki forystu um mótun stefnu samstæðunnar (Smerdon, 2007) og að haft sé eftirlit með pví að unnið sé til samræmis við hana.

\section{f) Samantekt}

Hér að framan hefur verið greint frá verklagi stefnumiðaðra stjórnarhátta hjá samstæðu OR og peim áskorunum sem fylgja pví að koma á samræmdu verklagi við mótun stefnu og eftirliti með framkvæmd hennar. Dæmið sýnir að í samstæðu OR er lögð mikil áhersla á að sérhver stefna, p.e. stefna í málaflokki og heildarstefna, sem stjórn móðurfélags og dótturfélaga bera ábyrgð á, sé rýnd reglulega, enda er vinna við mótun og útfærslu stefnu viðvarandi viðfangsefni hjá peim fyrirtækjum sem ætla sér að ná árangri (Runólfur Smári Steinpórsson, 2003a). Opinbert og skilgreint verklag er pó ekki pað eina sem skiptir máli í pessu samhengi eins og bent hefur verið á fyrr í pessum kafla. Fyrirtæki eru byggð upp af fólki. Allt sem par gerist er byggt á mannlegri hugsun og hegðun. Pess vegna skiptir öllu máli að pað ekki sé eingöngu fyrir hendi vel útfærð stefna og stefnuáætlun, heldur að líka sé fyrir hendi menning og hugarfar sem styður við verklagið og útfærir pað með samræmdum hætti til pess að áherslur stefnunnar nái fram að ganga og stefnan skili par með peim árangri sem henni er ætlað að skila og brugðist sé við ef tilætluðum árangri hefur ekki verið náð. Sé ekki tryggð samstilling stefnu og starfsfólks veldur pað margs konar núningi, óvissu og jafnvel andstöðu starfsfólks sem hamlar framkvæmd.

Niðurstöður rannsóknarinnar hafa ekki alhæfingargildi en pær varpa ljósi á pað hvernig hægt er að útfæra stefnutengt hlutverk stjórna og hafa pannig að mati höfunda hagnýtt gildi. Niðurstöðurnar hér að ofan fela í sér ákveðið framlag til fræðanna um stefnumiðaða stjórnarhætti pví pær varpa ákveðnu ljósi á stefnutengt hlutverk stjórna sem vantar pekkingu á, sér í lagi hvað varðar innleiðingu eða framkvæmd stefnu (Brauer og Schmidt, 2007; Daily o.fl., 2003; Fiegener, 2005; Hendry og Kiel, 2004; Pugliese o.fl., 2009; Runólfur Smári Steinpórsson, 2017; Schmidt og Brauer, 2006). Rannsóknin hér að framan kemur aftur á móti ekki inn á árangur af peim stefnumiðuðu stjórnarháttum sem tilvikið greinir frá, en pað gæti aftur verið grundvöllur að frekari rannsóknum, eins og komið er inn á hér á eftir.

Samantekið má segja að pessi raunrannsókn á stefnumiðuðum stjórnarháttum OR sé framlag til umræðu um stjórnarhætti í fyrirtæki í opinberri eigu (Calabró o.fl., 2013; Farrell, 2005; Grossi og Reichard, 2008; Hodges o.fl., 1996). Niðurstöðurnar eru jafnframt innlegg til að mæta skorti á pekkingu (e. knowledge gap) á sviði stefnutengdra stjórnarhátta 
pótt enn sé rík pörf fyrir fleiri rannsóknir á stjórnarháttum (e. governance mechanisms) (Calabró o.fl., 2013; Farrell, 2005; Grossi og Reichard, 2008). Raundæmið í rannsókninni er lýsandi um pað með hvaða hætti fyrirtæki í opinberri eigu vinnur að stefnumiðuðum stjórnarháttum til að dreifa valdi og ábyrgð. Rannsóknin einblínir á hlutverk stjórna tengt stefnu, sér í lagi innleiðingu stefnu sem hefur verið kallað eftir rannsóknum á (Brauer og Schmidt, 2007; Daily o.fl., 2003; Fiegener, 2005; Hendry og Kiel, 2004; Pugliese o.fl., 2009; Runólfur Smári Steinpórsson, 2017; Schmidt og Brauer, 2006), og dæmið um OR varpar ljósi á pað með hvaða hætti stjórn getur komið á fyrirkomulagi sem tryggir að unnið sé að innleiðingu stefnu.

\section{Lokaorð}

Stjórnarhættir fyrirtækja taka að mestu mið af aðstæðum, hefðum og venjum í viðkomandi landi og pví hefur engin ein alpjóðlega viðurkennd skilgreining á hugtakinu verið sett fram. Pröngar skilgreiningar hugtaksins leggja áherslu á fyrirtækið sjálft og eigendur pess en víðtækari skilgreiningar horfa auk pess til allra hagsmunaaðila. Stjórnir eru miðpunktur stjórnarhátta og ábyrgð peirra er mikil. Samkvæmt lögum bera stjórnir ábyrgð á starfsemi peirra fyrirtækja sem pær fara fyrir. Í fyrirtækjum í opinberri eigu parf að dreifa ábyrgð og auðlindum frá hinu opinbera til pessara fyrirtækja, sem aftur kallar á (endur) skipulagningu umboðs og valdmarka (Gnan o.fl., 2011).

Filatotchev og Boyd (2009) benda á að hlutverk stjórna sem tengist stefnu sé oft vanrækt í rannsóknum um fræðikenningar umboðsvanda. Enda horfir umboðsvandakenningin fyrst og fremst á pað pað hvernig hagsmunaárekstur getur orðið milli eigenda og stjórnenda og megináherslan er á eftirlit og stýringu til að afstýra pessum vanda. Með pví að setja OR eigendastefnu, sem er liður í innleiðingu stjórnarhátta og á ábyrgð stjórnar að fylgja, hafa eigendur reynt að takast á við pennan vanda. Framfylgd eigendastefnu má einnig tengja við kenningu um pjónustuhlutverk stjórna enda snúast helstu hlutverk stjórna um árangur fyrirtækisins sem á í hlut og eitt peirra hlutverka snýr að mótun og framvindu stefnu (Davis o.fl., 1997).

Rannsóknin á OR sem fjallað var um hér að framan hefur skilað framlagi sem tengja má við fræðin um stjórnarhætti á fjóra vegu. Í fyrsta lagi er rannsóknin dæmi um verkefni sem tekst á við stefnutengt hlutverk stjórna sem lítt hefur verið rannsakað, og pá sérstaklega hlutverk stjórna í tengslum við mótun og framkvæmd stefnu. Í öðru lagi er sýnt fram á gegnum verklag, lykilhugtök og lykilaðila með hvaða hætti stjórn sinnir pessu hlutverki. I priðja lagi er í pessari rannsókn byggt á frumgögnum sem er í takti við ákall fræðanna um að kafa dýpra í hið „,svarta box“ (Pugliese o.fl., 2009) í rannsóknum á hlutverki stjórna varðandi stefnumiðaða stjórnarhætti. Í fjórða lagi má sjá rannsóknina sem dæmi um eigindlega rannsókn á pessu sviði, en slíkar rannsóknir hafa verið fáar (Sjöstrand o.fl., 2016). Til viðbótar má nefna að rannsóknin er innlegg og dæmi um rannsókn á stefnumiðuðum stjórnarháttum par sem útgangspunkturinn er framkvæmd á vilja og markmiðum eigenda sem lýst er í eigendastefnu, en pað virðist vanta pekkingu, sérstaklega á pví sviði, eins og vikið var að í bæði inngangi og umræðukafla.

Rannsóknin á stefnumiðuðum stjórnarháttum innan samstæðu Orkuveitu Reykjavíkur (OR) hefur skilað peim niðurstöðum að fyrirtækið hefur skilgreint og próað tiltekið ferli og verkaskiptingu sem er löguð аð starfsemi og skipulagi samstæðunnar. Framlagið til stefnumiðaðra stjórnarhátta kemur mögulega skýrast fram niðurstöðum og umræðu um pað verklag sem OR hefur próað varðandi ferli og framvindu stefnu. Hvatinn að pessari próun virðist liggja í ákvörðun eigenda um að setja fyrirtækinu eigendastefnu og skýringar er líka að finna í breytingum á skipulagi fyrirtækisins og sérstökum aðstæðum pess eftir hrun íslenska fjármálakerfisins. Peir stefnumiðuðu stjórnarhættir sem OR hefur próað gera fyrirtækinu kleift að framfylgja eigendastefnu OR og tryggja að stjórn móðurfélagsins geti sinnt hinu stefnutengda hlutverki sínu.

Niðurstöður benda á mikilvægi pess að próa stefnumiðaða stjórnarhætti og beita peim 
gegnum samræmt verklag við alla pætti stefnumiðaðs starfs. Rannsóknin hefur jafnframt varpað ljósi á mikilvægi pess að styðjast ekki eingöngu við ritaðar leiðbeiningar og lýsingar á verklagi, heldur verður að tryggja að vinnulagið í heild verði inngreypt í menningu viðkomandi fyrirtækis svo raungera megi hina stefnumiðuðu stjórnarhætti. Rannsóknin bendir til að vinnubrögð af pessu tagi séu enn mikilvægari pegar um er að ræða samstæðuskipulag par sem stjórn móðurfélags parf að fylgja eftir eigendastefnu gagnvart dótturfélögum sem hvert um sig hafa stjórn sem ber að starfa í samræmi við almenn lög um hlutafélög.

Mikilvægt er að fylgja pessari rannsókn eftir með frekari rannsóknum. Nærtækt væri að víkka út pá rannsókn sem hér hefur verið greint frá og skoða nánar dæmið um stjórnarhætti OR. Par sem aðeins er um eitt dæmi að ræða er líka eðlilegt framhald að skoða hvernig er háttað með stefnumiðaða stjórnarhætti í fleiri íslenskum fyrirtækjum, bæði í opinberri eigu og hjá einkafyrirtækjum. Ef peir eru ekki til staðar hvernig koma megi við í (opinberum) rekstri stefnumiðuðum stjórnarháttum til að auka virkni og valddreifingu. Einnig mætti hugsa sér að skoða og meta virkni fyrirkomulags stefnumiðaðra stjórnarhátta par sem peir eru til staðar. •að er að segja hvernig stefnumiðaðir stjórnarhættir pjóna tilgangi sínu. Höfundar hvetja til frekari rannsókna á pessu sviði enda er brýn pörf í bæði fræðum og atvinnulífi.

\section{Heimildir}

Aguilera, R. V., Filatotchev, I., Gospel, H. og Jackson, G. (2008). An organizational approach to comparative corporate governance: Costs, contingencies, and complementarities. Organization Science, 19(3), 475-492. doi: $10.1287 /$ orsc.1070.0322

Ahrens, T., Filatotchev, I. og Thomsen, S. (2011). The Research Frontier in Corporate Governance. Journal of Management E Governance, 15(3), 311-325. doi: 10.1007/s10997-009-9115-8

Andrews, K. R. (1987). The Concept of Corporate Strategy. New York.

Ansoff, H.I. (1965). Corporate Strategy.New York: Wiley.

Auður Arna Arnardóttir og Pröstur Olaf Sigurjónsson. (2018). Restoring Trust Through Improved Corporate Governance and Adherence to Gender Quotas. Í Pröstur Olaf Sigurjónsson, David L. Schwarzkopf og Murry Bryant (ritstj.), The Return of Trust? Institutions and the Public after the Icelandic Financial Crisis (bls. 227244). London, UK: Emerald Publishing.

Auður Arna Arnardóttir og Pröstur Olaf Sigurjónsson. (2017). Gender Diversity on Boards in Iceland: Pathway to Gender Quota Law Following a Financial Crisis. Í C. Seierstad, P. Gabaldon og H. Mensi-Klarbach (ritstj.), Gender Diversity in the Boardroom (bls. 75-101). London: Palgrave Macmillan, Cham.

Bezemer, P.-J., Nicholson, G. og Pugliese, A. (2018). The influence of board chairs on director engagement: A case-based exploration of boardroom decision-making. Corporate Governance: An International Review, 26(3), 219-234. doi: /10.1111/corg.12234

Bonn, I. og Pettigrew, A. (2009). Towards a dynamic theory of boards: An organisational life cycle approach. Journal of Management \& Organization, 15(1), 2-16. doi: 10.1017/S1833367200002844

Brauer, M. og Schmidt, S. L. (2007). Defining the strategic role of boards and measuring board's effectiveness in strategy implementation. Corporate Governance, 8(5), 649-660. doi: 10.1108/14720700810913304

Calabró, A., Torchia, M. og Ranalli, F. (2013). Ownership and control in local public utilities: the Italian case. Journal of Management and Governance, 17, 835-862. doi: 10.1007/s10997-011-9206-1

Cardale, M. (2014). A Practical Guide to Corporate Governance (5. útg.). London: Sweet and Maxwell.

Chaffee, E. E. (1985). Three Models of Strategy. Academy of Management Review, 10(1), 89-96.

Chandler, A. D. (1962). Strategy and structure: chapters in the history of the industrial enterprise. Cambridge: M.I.T. Press.

Coase, R. H. (1937). The Nature of the Firm. Economica N.S., 4, 386-405.

Daily, C. M., Dalton, D. R. og Cannella, A. A. (2003). Corporate governance: decades of dialogue and data. Academy of Management Review, 28, 371-382.

Davis, J. H., Schoorman, F. D. og Donaldsson, L. (1997). Toward a Stewardship Theory of Management. Academy of Management Review, 22(1), 20-47.

Demb, A. og Neubauer, F. F. (1992). The Corporate Board: Confronting the Paradoxes. New York: Oxford University Press.

Drucker, P. (1974). Management: Tasks, Responsibilities and Practices. New York: Harper \& Row.

Eigendastefna Orkuveitu Reykjavíkur. (2014). Sótt 07.11.2016 af https://www.or.is/sites/default/files/eigendastefna_orkuveitu_reykjavikur.pdf. 
Eisenhardt, K. M. (1989). Building Theories from Case Study Research. The Academy of Management Review, 14(4), 532-550. doi: 10.2307/258557

Eisenhardt, K. M. og Graebner, M. E. (2007). Theory Building from Cases: Opportunities and Challenges. Academy of Management Journal, 50(1), 25-32. doi: 10.5465/AMJ.2007.24160888

Erna Sigurðardóttir. (2003). Stjórnir hlutafélaga, starfshættir og ábyrgð (óbirt MS-ritgerð). Háskóli Íslands, Reykjavík.

Eypór Ívar Jónsson. (2005). The Role Model of the Board: a preliminary study of the roles of Icelandic boards. Corporate Governance: An International Review, 13(5), 710-717.

Eypór Ivar Jónsson. (2007). Price fixing in the Icelandic Oil and Gas Industry: where were the boards. International Journal of Business Governance and Ethics, 3(2), 163-178.

Eypór Ívar Jónsson. (2008). The Role of Boards of Directors and the Relationship with Organisational Performance: An Empirical Investigation into Small and Medium Sized Enterprises in Iceland (doktorsritgerð). Henley Management College/Brunel University, London

Eypór Ívar Jónsson. (2013). One role is not big enough: a multi-theoretical study of board roles in SMEs. International Journal of Business Governance and Ethics, 8(1), 50-68.

Fama, E. F. og Jensen, M.C. (1983). Separation of Ownership and Control. The Journal of Law E Economics, 26( 2), 301-325.

Farrell, D. (2005). Offshoring: Value creation through economic change. Journal of Management Studies, 42(3), 675-683.

Filatotchev, I. og Boyd, B. K. (2009). Taking Stock of Corporate Governance Research While Looking to the Future. Corporate Governance: An International Review, 17(3), 257-265.

Fiegener, M. K. (2005). Determinants of board participation in the strategic decisions of small corporations. Entrepreneurship Theory and Practice, 29(5), 627-650. doi: 10.1111/j.1540-6520.2005.00101.x

Fjármála- og efnahagsráðuneytið. (2017). Almenn eigendastefna ríkisins fyrir fjármálafyrirtæki: Nær til fjármálafyrirtækja sem Bankasýsla ríkisins hefur umsjón með. Sótt 1.10.2018 af http://bankasysla.is/files/Almenn\%20eigandastefna\%20r\%C3\%ADkisins\%20fyrir\%20fj\%C3\%A1rm\%C3\%A1lafyrirt\%C3\%A6ki\%202017_363633104.pdf

Freeman, E. R. (1994). The Politics of Stakeholder Theory: Some Future Directions. Business Ethics Quarterly, 4(4), 409-421.

Gnan, L., Hinna, A., Monteduro, F. og Scarozza, D. (2011). Corporate governance and management practices: stakeholder involvement, quality and sustainability tools adoption. Journal of Management and Governance, 17(4), 907-937.

Goold, M. og Campbell, A. (1990). Non-executive director's role in strategy. Long Range Planning, 23(6), 18-19.

Grant, R. M. (2010). Contemporary Strategy Analysis. West Sussex, UK: John Wiley \& Sons, Ltd.

Grossi, G. og Reichard, C. (2008). Municipal corporization in German and Italy. Public Administration Review, 10(5), 597-617.

Guðbjörg Linda Rafnsdóttir, Porgerður Einarsdóttir og Jón Snorri Snorrason. (2014). Gender Quota on the Boards of Corporations in Iceland. Í M. D. Vos og P. Culliford (ritstj.), Gender Quotas for Company Boards (bls.147-156). Cambrigde: Trinity House.

Guðrún Erla Jónsdóttir. (2015). Skýrsla um framfylgd eigendastefnu. Reykjavík: Orkuveita Reykjavíkur.

Guðrún Erla Jónsdóttir. (2016). Skýrsla um framfylgd eigendastefnu OR á árinu 2016. Reykjavík: Orkuveita Reykjavíkur.

Guðrún Erla Jónsdóttir (ritstjóri). (2017). OR bókin: Handbók OR samstæðunnar. Reykjavík: Orkuveita Reykjavíkur.

Guðrún Erla Jónsdóttir. (2018). A question of trust: The story of Reykjavík Energy. Í Pröstur Olaf Sigurjónsson, D. L. Schwarzkopf og M. Bryant (ritstj.), The Return of Trust? Institutions and the Public after the Icelandic Financial Crisis (bls. 129-149). London, UK: Emerald Publishing.

Helmer, H. W. (1996). A director's role in strategy. Directors and Boards, 20, 22-25.

Hendry, K. og Kiel, G. C. (2004). The role of the board in firm strategy: integrating agency and organizational control perspectives. Corporate Governance: An International Review, 12, 500-520.

Ingi Rúnar Eðvarðsson, Runólfur Smári Steinpórsson og Helgi Gestsson (2011). Stefnumótun í íslenskum skipulagsheildum. Stjórnmál \& stjórnsýsla, 7(1), 73-96.

Jensen, M. C. og Meckling, W. (1976). Theory of the firm: Managerial behavior, agency costs and ownership structure. Journal of Financial Economics, 3(4), 305-350.

Johnson, J. L., Daily, C. M. og Ellstrand, A. E. (1996). Boards of Directors: A Review and Research Agenda. Journal of Management, 22(3), 409-438. doi: 10.1177/014920639602200303

Johnson, G., Scholes, K. og Whittington, R. (2008). Exploring Corporate Strategy. Essex: Pearson Education Limited.

Judge, W. Q., Jr., og Zeithaml, C. P. 1992. Institutional and strategic choice perspectives on board involvement in the strategic decision making process. Academy of Management Journal, 35, 766-794.

Kirkpatrick, G. (2009). Corporate Governance Lessons from the Financial Crisis. OECD Journal: Financial Market Trends, 2009(1), 61-87.

L'Huillier, B. M. (2014). What does “corporate governance" actually mean? Corporate Governance, 14(3), 300319. Doi: 10.1108/CG-10-2012-0073 
Lilja Rún Ágústsdóttir. (2010). Stjórnarhættir fyrirtækja. Íslenskt sjónarmið (óbirt MSc ritgerð). Háskóli Íslands, Reykjavík.

Lög um Orkuveitu Reykjavíkur nr. 136/2013. Sótt 07.11.2016 af http://www.althingi.is/lagas/nuna/2013136. html

Mallin, C. A. (2004). Corporate Governance. New York: Oxford University Press.

McNulty, T., og Pettigrew, A. (1999). Strategists on the Board. Organization Studies, 20(1), 47-74. https://doi. org/10.1177/0170840699201003

McNulty, T., Zattoni, A., og Douglas, T. (2013). Developing Corporate Governance Research through Qualitative Methods: A Review of Previous Studies. Corporate Governance: An International Review, 21(2), 183-198. doi: 10.1111/corg.12006

Margrét Pétursdóttir, Ása Ólafsdóttir, Ómar H. Kristmundsson og Gestur Páll Reynisson. (2012). Skýrsla úttektarnefndar um Orkuveitu Reykjavíkur. Reykjavíkurborg, úttektarnefnd um Orkuveitu Reykjavíkur.

Mintzberg, H., Ahlstrand, B. og Lampel, J. (1998). Strategy Safari: A Guided Tour Through the Wilds of Strategic Management. New York, NY: The Free Press.

Pfeffer, J. og Salancik, G. R. (1978). The External Control of Organizations: A Resource Dependency Perspective. New York: Harper and Row Publishers.

Pirson, M. og Turnbull, S. (2015). The future of corporate governance: Network governance - A lesson from the financial crisis. Human Systems Management, 34, 81-89. doi: 10.3233/HSM-150834

Porter, M. E. (1996). What is Strategy? Harvard Business Review, 74(6), 61-78.

Pugliese, A., Bezemer, P. J., Zattoni, A., Huse, M., Van den Bosch, A., J. og Volberda, H. W. (2009). Board of Direcors' Contribution to Strategy: A Literature Review and Research Agenda. Corporate Governance: An International Review, 17(3), 292-306.

Pye, A. J. og Pettigrew, A. M. (2005). Studying board context process and dynamics: some challenges for the future. British Journal for Management, 16, 27-38.

Rannsóknarmiðstöð um stjórnarhætti. (2018). Fyrirmyndarfyrirtæki í stjórnarháttum. Sótt 1.10.2018 af http://ibr. hi.is/fyrirmyndarfyrirtaeki_i_godum_stjornarhattum.

Raforkulög nr. 65/2003. Sótt 07.11.2016 af http://www.althingi.is/lagas/nuna/2003065.html

Rindova, V. P. (1999). What corporate boards have to do with strategy: a cognitive perspective. Journal of Management Studies, 36(7), 953-975.

Runólfur Smári Steinpórsson. (2003a). Stefnumiðuð stjórnun: Fimm greiningarlíkön. Tímarit um viðskipti og efnahagsmál, 2003(1), 27-54.

Runólfur Smári Steinpórsson. (2003b). Lýsing á stefnu og stefnumótunarvinnu. Í Ingjaldur Hannibalsson (ritstj.), Rannsóknir i félagsvísindum IV: Viðskipta- og hagfræðideild (bls. 317-329). Reykjavík: Háskólaútgáfan.

Runólfur Smári Steinpórsson. (2017). Stjórnarhættir og stefnutengt hlutverk stjórna. Góđir stjórnarhættir: Rannsóknarmiðstöð um stjórnarhætti, 2017(1), 20-23.

Runólfur Smári Steinpórsson, Anna Marín Pórarinsdóttir og Einar Svansson. (2018). Skipulag fyrirtækja á Íslandi fyrir og eftir hrun. Tímarit um viðskipti og efnahagsmál, 15(1), 87-109. doi: 10.24122/tve.a.2018.15.1.5

Sameignarsamningur. (2014). Sótt 07.11.2016 af https://www.or.is/sites/default/files/sameignarsamningur_ orkuveitu_reykjavikur.pdf

Schmidt, S. L. og Brauer, M. (2006). Strategic Governance: how to assess board effectiveness in guiding strategy execution. Corporate Governance: An International Review, 14(1), 13-22.

Skýrsla rannsóknarnefndar Alpingis. (2010). Sótt 1.10.2018 af https://www.rna.is/eldri-nefndir/addragandiog-orsakir-falls-islensku-bankanna-2008/skyrsla-nefndarinnar/

Smerdon, R. (2007). A Practical Guide to Corporate Governance (3. útg.). London: Sweet and Maxwell.

Solomon, J. og Solomon, A. (2004). Corporate Governance and Accountability. West Sussex: John Wiley \& Sons, Ltd.

Strouhal, J., Bonaci, C. og Mustata, R. (2012). Corporate Governance and Financial Crisis. International Advances in Economic Research, 18(1), 122-123.

Taylor, S. J. og Bogdan, R. (1998). Introduction to qualitative research method: A guidebook and resource. New York: John Wiley \& Sons, Inc.

Thomsen, S. (2008). An introduction to Corporate Governance: Mechanisms and Systems. Copenhagen: Djøf Publishing.

Viðskiptaráð Íslands, Kauphöll Íslands og Samtök Atvinnulífsins. (2004). Stjórnarhættir fyrirtækja: Leiðbeiningar. Reykjavík: Höfundar.

Viðskiptaráð Íslands, Kauphöll Íslands og Samtök Atvinnulífsins. (2008). Stjórnarhættir opinberra fyrirtækja: Leiðbeiningar. Reykjavík: Höfundar.

Viðskiptaráð Íslands, Kauphöll Íslands og Samtök Atvinnulífsins. (2009). Stjórnarhættir fyrirtækja: Leiðbeiningar. Reykjavík: Höfundar.

Willamsson, O. E. (1975). Markets and Hierarchies. New York: Free Press.

Yin, R. K. (2009). Case study research: Design and methods. Los Angeles: SAGE Publications, Inc.

Zahra, S. A. (1990). Increasing the board's involvement in strategy. Long Range Planning, 23(6), 109-117.

Pröstur Olaf Sigurjónsson. (2010). The Icelandic Bank collapse: challenges to governance and risk management. Corporate Governance: The international journal of business in society, 10(1), 33-45. 


\section{Viðauki - yfirlit yfir gögn}

\begin{tabular}{|c|c|c|}
\hline \multicolumn{3}{|l|}{ Aðgengileg gögn } \\
\hline Eigendastefna 2014 & $\begin{array}{l}\text { Eigendastefna Orkuveitu } \\
\text { Reykjavíkur } 2014\end{array}$ & $\begin{array}{l}\text { Sótt } 07.11 .2016 \text { af https://www.or.is/sites/ } \\
\text { default/files/eigendastefna_orkuveitu__ } \\
\text { reykjavikur.pdf }\end{array}$ \\
\hline Handbók OR & $\begin{array}{l}\text { OR bókin: Handbók OR } \\
\text { samstæðunnar. Reykjavík: } \\
\text { Orkuveita Reykjavíkur. }\end{array}$ & Guðrún Erla Jónsdóttir (ritstjóri). (2017). \\
\hline Lög um OR & $\begin{array}{l}\text { Lög um Orkuveitu Reykjavíkur nr. } \\
\text { 136/2013. (2013). }\end{array}$ & $\begin{array}{l}\text { Sótt 07.11.2016 af http://www.althingi.is/ } \\
\text { lagas/nuna/2013136.html,. }\end{array}$ \\
\hline Raforkulög & Raforkulög nr. 65/2003. (2003). & $\begin{array}{l}\text { Sótt 07.11.2016 af http://www.althingi.is/ } \\
\text { lagas/nuna/2003065.html }\end{array}$ \\
\hline Sameignarsamningur & Sameignarsamningur. (2014). & $\begin{array}{l}\text { Sótt 07.11.2016 af https://www.or.is/ } \\
\text { sites/default/files/sameignarsamningur_ } \\
\text { orkuveitu_reykjavikur.pdf,. }\end{array}$ \\
\hline Skýrsla & $\begin{array}{l}\text { Skýrsla um framfylgd } \\
\text { eigendastefnu. Reykjavík: } \\
\text { Orkuveita Reykjavíkur. }\end{array}$ & Guðrún Erla Jónsdóttir. (2015). \\
\hline Skýrsla & $\begin{array}{l}\text { Skýrsla um framfylgd } \\
\text { eigendastefnu OR á árinu } 2016 . \\
\text { Reykjavík: Orkuveita Reykjavíkur. }\end{array}$ & Guðrún Erla Jónsdóttir. (2016). \\
\hline Skýrsla & $\begin{array}{l}\text { Skýrsla úttektarnefndar um } \\
\text { Orkuveitu Reykjavíkur: Október } \\
\text { 2012. }\end{array}$ & Margrét Pétursdóttir o.fl. (2012). \\
\hline Fundargerðir OR & Heimasíða Orkuveitu Reykjavíkur & www.or.is/utgefid-efni \\
\hline \multicolumn{3}{|l|}{ Innanhússgögn } \\
\hline Eigendastefna 2012 & $\begin{array}{l}\text { Eigendastefna Orkuveitu } \\
\text { Reykjavíkur } 2012\end{array}$ & \\
\hline Kynningar & $\begin{array}{l}\text { Stefnumiðaðir stjórnarhættir innan } \\
\text { OR } 2016 \text { og } 2017\end{array}$ & \\
\hline Kynning & $\begin{array}{l}\text { Stefnuáætlanir í samstæðu OR } \\
2017\end{array}$ & \\
\hline Rekstrarhandbókarskjal & Skipulag samstæðu OR & $\begin{array}{l}\text { Sótt } 10.01 .2017 \text { af https://www.or.is/um-or/ } \\
\text { skipulag-og-stjornendur }\end{array}$ \\
\hline Rekstrarhandbókarskjöl & Sérhver stefna í samstæðu OR & \\
\hline Rekstrarhandbókarskjal & $\begin{array}{l}\text { Yfirlit yfir stefnuskjöl í samstæðu } \\
\text { OR }\end{array}$ & \\
\hline Rekstrarhandbókarskjöl & $\begin{array}{l}\text { Sérhver árangursmælikvarði í } \\
\text { samstæðu OR }\end{array}$ & \\
\hline \multicolumn{3}{|l|}{ Bein athugun } \\
\hline Stjórnarfundir OR & $2016-2017$ & $\begin{array}{l}\text { Bein athugun á umræðum um stefnur og } \\
\text { stefnuverkefni og skýrslu um framfylgd } \\
\text { eigendastefnu } \\
\text { 2016: SF226, SF229, SF231, SF232, SF234, } \\
\text { SF236, SF237, SF238, aðalfundargerð, } \\
\text { fundargerð eigendafundar } \\
\text { 2017: SF239, SF240, SF245, SF246, SF247, } \\
\text { SF248, SF252, SF253, aðalfundargerð, } \\
\text { fundargerð eigendafundar }\end{array}$ \\
\hline $\begin{array}{l}\text { Fundargerðir stjórnar } \\
\text { OR }\end{array}$ & $2016-2017$ & $\begin{array}{l}\text { Fundargerðir yfirfarnar } \\
\text { 2016: SF226-SF238 } \\
\text { 2017: SF239-SF253 }\end{array}$ \\
\hline Viðtöl & & \\
\hline
\end{tabular}




\begin{tabular}{ll}
\hline Stjórnandi 1 & Viðtal tekið dags. 26.06.2016 \\
\hline Stjórnandi 2 & Viðtal tekið dags. 26.06.2016 \\
\hline Stjórnandi 3 & Viðtal tekið dags. 26.06.2016 \\
\hline Stjórnandi 4 & Viðtal tekið dags 28.06.2017 \\
\hline
\end{tabular}


